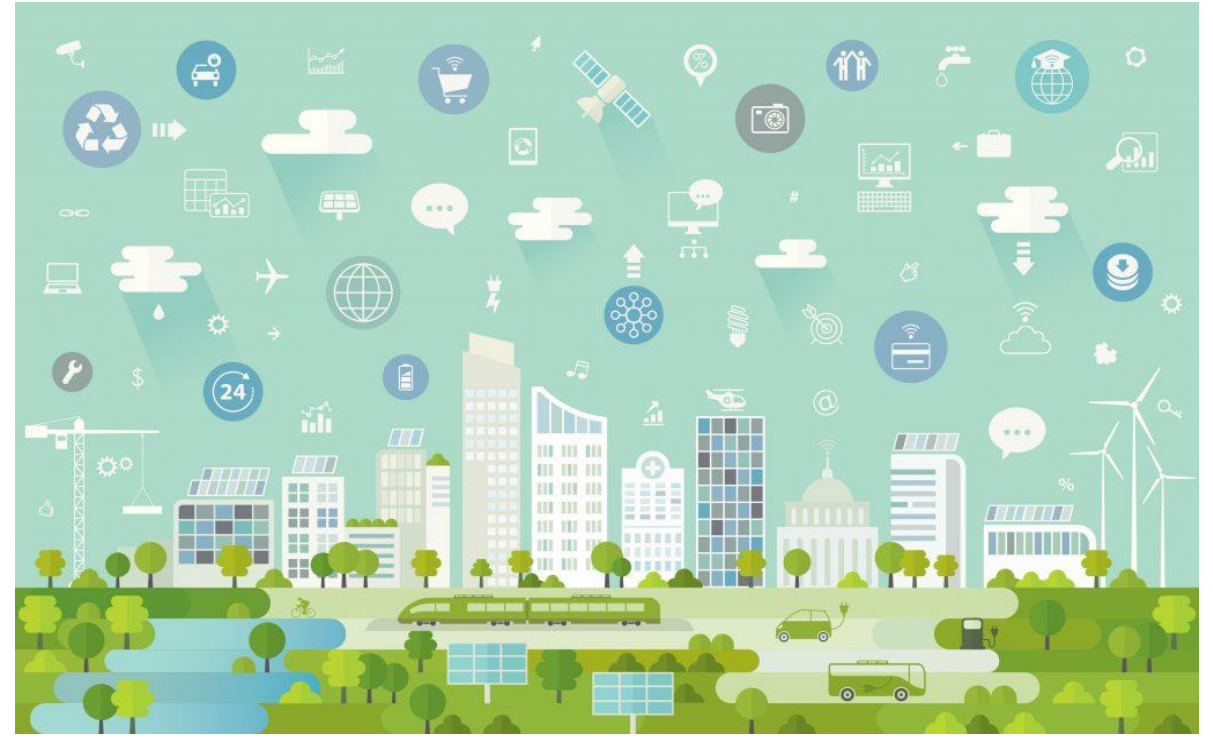

\section{SMART SUSTAINABLE CITIES}

A qualitative study of Aarhus's third way approach to the smart city concept
MASTER THESIS

Nordic Urban Planning Studies at Roskilde University, Institute for People and Technology

Spring 2021

Author:

Anne Sofie Kudsk Jørgensen (54520)

Supervision:

Majken Toftager Larsen 


\section{Summery}

The aim of this thesis is to examine Aarhus's third way approach to the smart city concept and seek to understand the relationship between the concept and sustainability as a development goal. Throughout the thesis, a conceptual focus on sustainability is deployed, and by using qualitative document analysis as a main method, an analysis of the smart city concept through the lens of sustainability is conducted.

The analysis is centered around two main objectives, namely the aim of developing a deeper understanding of the smart city concept in the context of Aarhus, and the aim of understanding how the concept is enacted by the city. The first sections of the analysis addresses Aarhus's vision and approach to the smart city concept, furthermore, the latter part of the analysis is dedicated to analyzing the enactment of Aarhus's smart city approach. The thesis is informed by a critical theoretical framework, which serves as a conceptual and theoretical base and starting point for discussing and relating the findings of the document analysis, to a broader context.

The overall conclusion of the thesis is that while Aarhus truly aim to provide an alternative approach to the smart city concept, for the most part, their vision resembles what is found in other aspiring smart cities. The analysis finds, that despite ambitious goals, sustainable development is a wicked problem, which is unlikely to be solved through deployment of smart city technologies alone. Moreover, the analysis finds that rearrangement of power relations and private actor's involvement, are smart city features that challenge social sustainability, as private sector actors are guided by profit, and not necessarily what's best for the majority. These arguments as led the thesis to conclude, that questions about power relations, economic motivations, and fundamental challenges with merging economic, social, and environmental interests in the city, may prevent Aarhus from achieving sustainable development through their promising smart city vision.

Keywords: The Smart city concept, Sustainable Urban Development, Urban Planning, Smart City Vision, Smart Technologies, Smart City Partnerships, Smart City Living Labs, Urban Testbeds, Urban Policy Making. 


\section{Table of contents}

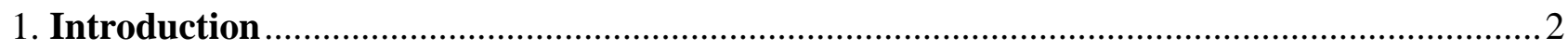

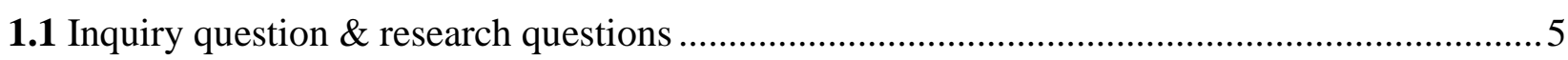

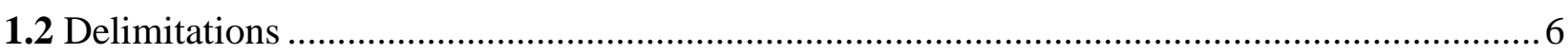

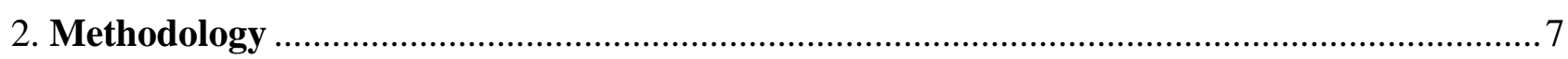

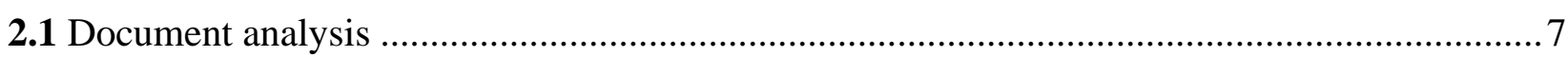

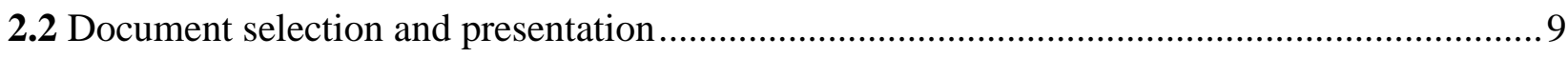

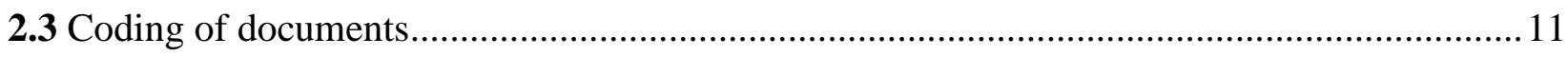

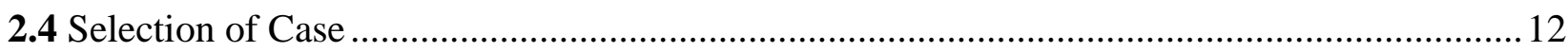

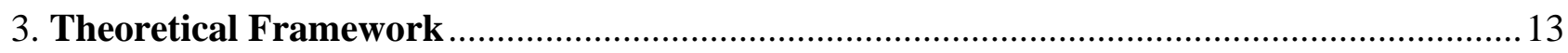

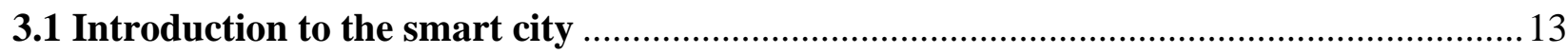

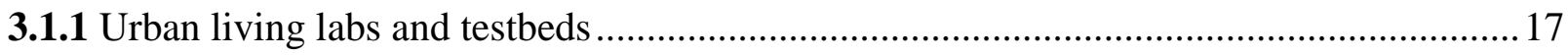

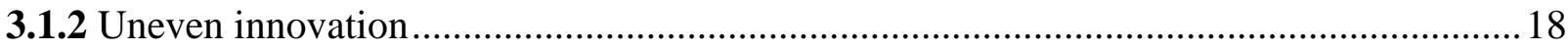

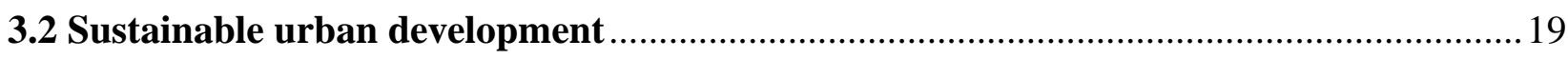

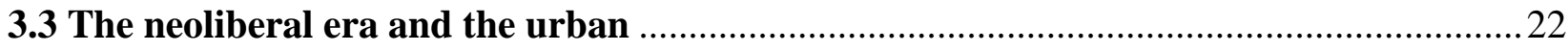

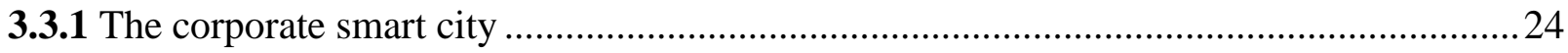

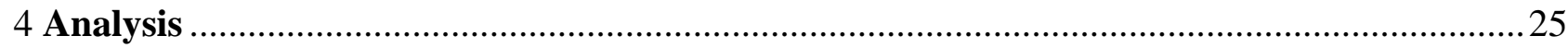

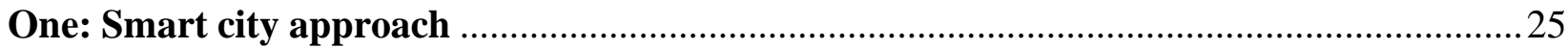

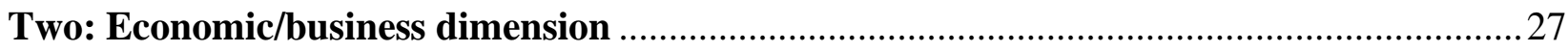

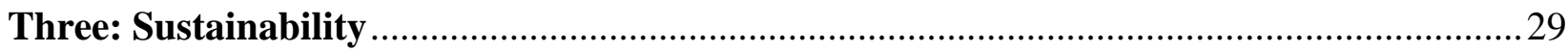

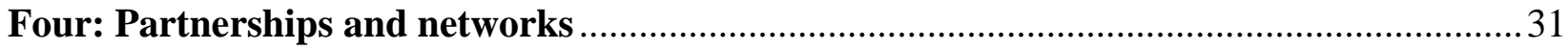

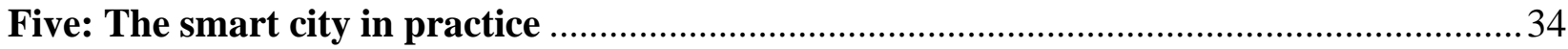

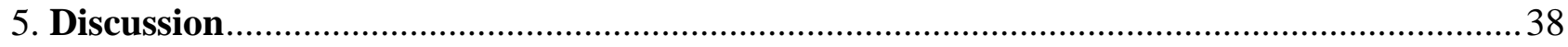

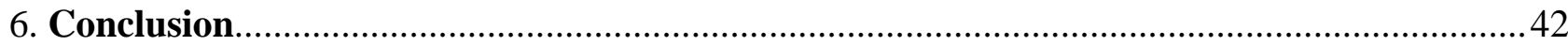

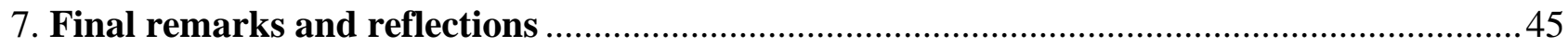

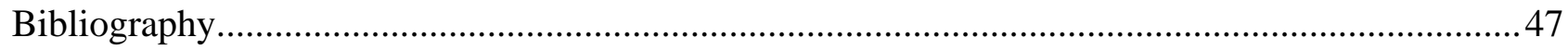




\section{Introduction}

The history of humankind is the history of people in cities. In the $21^{\text {st }}$ century, the human population is booming, and people find their ways to urban areas in numbers never seen before in previous times (Hollands, 2008). Urban areas now cover about 3\% of planet earth's surface and the number is predicted to grow in the future. At this time, out of the earth's seven billion people, about four billion are now living in urban areas, and by 2050, this number is predicted to rise to an estimated six billion urban dwellers (Snow, et al., 2016). Generally, urbanization has worked well for human species, who has prospered from all the things that make cities work and succeed on a daily basis (Clark, 2020). However, the increasing pressure on nowadays cities to make room for a growing urban population, has made questions about resource - scarcity and urban density a main concern for city administrations and urban planners all over the world. While we plan to expand, rebuild, and restructure our cities, added into the mix of our future challenges is a climate crisis that is threatening to amplify the challenges that lay ahead of us (Dawson, 2017). Cities are the main contributors to climate change due to the massive amounts of greenhouse gas emissions created by activities related to, and in cities. While cities contribute greatly to accelerate climate change, they are also major hubs for global economy, which we all rely on. It is estimated that in the future, the world's 600 largest cities will be accounting for more than 60\% of the worlds GDP by 2025 (Snow, et al., 2016). Thus, the great dilemma of current time is to find ways to ensure prosperity while developing and running cities in ways that are not harmful to the environment. This means, that cities have embarked on one of the most challenging transformational journeys to date, pursuing answers to how the urban can be restructured in new sustainable ways, while still satisfying an evergrowing demand for urban livability and prosperity.

In the hunt for solutions, cities look to innovation and technological solutions, and the promises of new smart city technologies are to a large extent considered crucial for succeeding with sustainable urban transitions. Universally, we have for the most part come to accept, that smart technologies are key to ensuring a sustainable urban future. And the smart city concept as thus emerged as a respond 
to increased demand for smart tech solutions. Smart city visions come in many forms, and the most passionate smart city advocates of our time, envision smart cities entirely run by new technologies that are yet to be invented, and existing ones such as IoT, ICT, artificial intelligence, big data, blockchain and sensor technologies (Lisdorf, 2020). The smart city concept is most often conveyed as a holistic approach to urban development. By leveraging and implementing technological solutions, the smart city concept is considered ideal for optimizing and streamlining cities while solving social problems and working as a catalyst for economic growth (Hollands, 2008). As aiming towards zero emission cities, and sustainable development has become an established goal for cities across the globe, smart city technologies are often embedded in green city goals and thereby seek to deliver sustainable solutions to cities. As a result, during the past decade, the technological aspects of the smart city concept, has ever more often been employed to address environmental issues in cities, and thereby linking the smart city concept to sustainable urban development (Clark, 2020).

Although smart technologies are undoubtably an essential part of our urban future, the nearly utopian and flawless concept that the smart city is regularly portrayed as, has received considerable critique by actors across disciplines and sectors. During the past decade, a growing body of critical literature about the smart city concept has been published, and scholars of social science and critical urban studies are challenging the portrayal of the smart city as a solution to all urban problems (Clark, 2020; Hollands, 2013; Hollands, 2008; Vanolo, 2014). Although the smart city concept claims to create cities for people, critical scholars and observers of the smart cities project express skepticism and ask for exactly whom the smart city intended. Moreover, while technological solutions and engineering is recognized as essential for a green transition and reduction in urban $\mathrm{CO} 2$ emissions, the fix -it- all solution that the smart city claim to be, is challenged by those who argue, that matters associated to people and communities are neglected in practice, and that the smart city therefore fail to fulfill its self-proclaimed goal of putting people first (Clark, 2020). At its very essence, critical scholars argue that the smart city concept should be understood as a top-down approach based on technocratic values and born out of a neoliberal era, and therefore often neglect the importance of democratic participation, inclusion, and equity (ibid). Furthermore, among researchers, there exist a concern about questions related to digital innovation and digital inclusion in the smart city. For some scholars, the main concern is that emerging smart technologies may have the capacity to produce and exacerbate inequalities in cities, as urban development driven by 
the tech sector often disregard important social aspects of urban planning which can result in communities and cities becoming less equitable (Clark, 2020, Hollands, 2008),

Despite critique and concern about smart city projects continue to be raised, the concept has continued to gain momentum, and it has grown stronger during the past decade. According to research, the reason must be found in the fact that the concept is largely known and accepted as being a pathway to solving urban problems, ensuring prosperous cites and supporting national economies. As the worlds cities and urban areas continue to grow larger in scale and citizen numbers, the global market for smart city solutions is projected grow with it. In 2014, the global market for technological smart city solutions was estimated to be $\$ 8.8$ billion. While $\$ 8.8$ billion is a significant number, the market is expecting to grow rapidly, and in 2023, the global smart city market is expected to reach a value of $\$ 27.5$ billion yearly and is believed to continue its fast growth (Grossi \& Pianezzi, 2017, p. 82).

In a Danish context, conversations about smart cities have moved to the very heart of discussions about future development of Danish cities and urban areas. Like the rest of the world, the smart city concept and smart innovation has received increasing interest throughout the past decade, as both academia and the private and public sectors has shown great interest in the concept. In Denmark, the smart city concept has been embraced by decision makers on both city, regional and state level, and it is widely accepted that smart technologies are an essential part of Denmark's future. In cities all over the country, pilot projects, urban testbeds and living labs are implemented at city level and research and development projects are well funded and ever growing in numbers.

Denmark has, like other countries, identified the economic opportunity that the smart city is believed to be, and on national level, an innovation strategy has been created around it. This means that Denmark as a country, has decided to target the smart city market, by seeking to push and support smart city innovation, implementation, testing and export. According to the ministry of foreign affairs' department 'invest in Denmark', Denmark is perceived as a growing market for smart city solutions, and businesses worldwide has identified Denmark's testing capacity and demonstration facilities among the leading in the world. In addition to strong test- and demonstration facilities, Danish municipalities play an important role in Denmark's smart city development, as their commitment and willingness to working with the concept is emphasized has unique. It is often the case, that the Danish approach, being a mix of municipal commitment, strong research capacities and approach to development of smart city technologies is emphasized as 
attractive feature for global investors (Ministry of foreign affairs of Denmark - invest in Denmark, 2016). Furthermore, Denmark's well developed - and well-run digital infrastructure also play a great role in Danish smart city activities. With Denmark's decision to make all public organizations paperless in 2014, a perfect situation was created for data collection, testing, and implementation of smart technologies (Snow, et al., 2016). Adding-on to the previously mentioned, the Danish smart city approach is most often found to be connected to green city agendas and sustainable urban development (Joss, et al., 2019). The Danish smart city approach should therefore be understood as closely connected to green development goals and national green targets such as Denmark's national target of becoming fossil -free by 2050 (Ministry of foreign affairs of Denmark - invest in Denmark, 2016).

As the promise of new, more, and better seem to be the essence of the smart city concept, the concept is for obvious reasons appealing to urban planners, dwellers, and elected officials who strive for more efficiency, more resiliency, more green development, more sustainability, and more inclusive cities. However, despite appealing smart city visions and high prioritization of smart technologies in many cities, the question of whether the smart city concept has the potential to provide solutions for, at times, highly contradicting challenges simply by deploying smart technologies remain to be proven. The objective of this thesis is to explore this dilemma in the context of Denmark's second largest city, Aarhus. Through a conceptual focus on sustainability, the thesis aims to explore Aarhus third way approach to the smart city concept through the lens of sustainability.

\subsection{Inquiry question \& research questions}

By conducting a study into the smart city concept in the context of Denmark's second largest city Aarhus, the overall aim is to develop a deeper understanding of the smart city concept in a Danish context, while seeking to understand the relationship between the smart city concept and sustainability in Aarhus. To develop a better understating of how the smart city project materialize in Aarhus, an analysis of smart city initiatives and activities is conducted in the latter part of the analysis. Aarhus's vision and enactment of the smart city concept is investigated by conducting desk research, using document analysis as a main method. Moreover, to further understand the broader context of the smart city approach, and as a starting point for further discissions about 
sustainability and the smart city concept, a conceptual and theoretical framework mainly informed by critical urban theory is applied to the thesis. The inquiry question guiding the research of this thesis is as follows:

Based on documents published by (and on behalf of) Aarhus, what characterize the city's approach to the smart city concept, and how may the relationship between sustainability and the smart city approach be defined? How does the approach direct sustainability practices?

\section{Research questions:}

1. Based on the documents and mapping of smart city activities, do Aarhus's third way approach offer a model that is significantly different from what is presented in the literature informing this thesis?

2. How is sustainability understood according to the smart city vision and activities, and how may this understanding influence sustainable development in Aarhus?

3. In what ways may Aarhus be influenced by their strong commitment to the smart city concept, and what risks can this lead to?

\subsection{Delimitations}

The aim of this thesis is not to provide an analysis of smart city technologies and their specific features, abilities, and qualities, nor is the goal to provide an in-depth analysis of implementation process for adaptation and enactment of the smart city concept. This thesis is rather aimed at exploring the smart city as a concept, while seeking to understand the impact it may have on sustainable policy making in the city. Here, the aim is not to provide an in-depth analysis of policy making process in Aarhus, but rather to understand how the smart city as a concept, may affect their development. Moreover, the thesis deploys sustainability as a conceptual focus, and while the analysis is conducted through the lens of sustainability, the aim is not to assess and study specific sustainable activities and solutions meticulously, instead, the thesis examines sustainability as a model and concept for achieving goals. 


\section{Methodology}

This thesis applies document analysis as a qualitative method for uncovering data about the smart city concept in the context of Aarhus, and thereby develop a greater understanding of the city's approach to the smart city project and urban development. The following sections are dedicated to presenting how document analysis as a qualitative method has been applied in this study. Furthermore, the latter section will present the coding process approach used in the thesis.

\subsection{Document analysis}

Like any other research method, document analysis has both strengths and weaknesses, as well as advantages and limitations. However, as documents can be useful in uncovering meaning and provide important insights into a research problem, this study is conducted using documentary sources as primary data collection method.

Document analysis is a systemic procedure applied by the researcher in his or her reviewing and evaluation of documents (Bowen, 2009). A broad spectrum of materials can be included as "documents" when applying document analysis as a method in qualitative social studies. These document types include everything from agendas, institutional reports, PowerPoint presentations, proposals, journals, letters, scrapbooks, scripts and many more (Coffey, 2013, pp. 367-368). Document analysis has been an important part of qualitative research for many years, however, in previous studies where the method has been applied, it is often found, that there has been provided insufficient details of the procedures followed by the researcher in his or her handling of documents. Furthermore, in some cases, document analysis is not utilized efficiently and thereby the method has not always lived up to its full potentials (Bowen, 2009). In this thesis, the pitfalls pointed to by Bowen (2009), has been considered carefully, and the approach adopted in this thesis therefore seek to follow a systematic and structured procedure for handling, reviewing, and evaluating the documents selected for the study.

Even though document analysis has weaknesses and limitations when not approached in a structured manner, the method has been chosen for this thesis, as it provides an effective approach to uncovering data, facts and conditions relate to the smart city concept in the context of Aarhus, which may not have been accessible using other methods. According to Amanda Coffey (2013), 
documents should be seen and understood as mirrors of society and she refer to them as 'social facts' as they are produced, distributed, and utilized in ways that are socially organized (Coffey, 2013). By understanding the documents analyzed in this thesis as social facts, applying this method to the study will provide a greater understating of how the smart city concept is approached and practiced in the context of Aarhus. One of document analysis major advantageous is the methods ability to be unaffected by the investigation and research process. As documents contain word and images that is free from researchers' intervention, document analysis does, in oppose to some other qualitative methods offer data that has not been influenced or altered by the researcher during both the data collection and research process (Bowen, 2009). This means, that the data extracted from the selected documents has not been influenced or altered by the presence of a researcher, but rather, the data is non - reactive and thereby fixed. The fact that document analysis provide raw unaltered data is an important reason for choosing this method, as the thesis seek to understand how the smart city concept is largely communicated and understood, and therefor do not look for personal accounts and narratives. Furthermore, many interests are tied to the smart city concept, and the use of alternative qualitative research methods in the study, could have led biased accounts by actors influenced by the researcher's presence, or their own position or interests. However, with that said, it is important to note that document analysis is not a method free from bias and it may suffer from biased selectivity as the researcher may possibly be biased when selecting data. Moreover, the documents available for the researcher may be representing and promoting certain interests over others (Bowen, 2009). This condition is clearly true for the documents included in this study, and they must all be considered as promoting the interests of Aarhus as an aspiring smart city, and other smart city actors who has a stake in Denmark's smart city engagement.

The availability factor is one of the major advantages of using document analysis as a research method for this thesis. Mainly due to the internet and rapid distribution of knowledge in the $21^{\text {st }}$ century, large amounts of data are easily shared and accessed which makes document analysis an attractive option for qualitative studies. As various documents are frequently published about the smart city project by both public and private actors, the method allow this thesis to make use of the large amount of data for eliciting meaning and developing a broader understanding of the smart city concept in the context of Denmark's second largest city.

Parallel to other qualitative research methods, for the researcher to elicit meaning from his or her research process, document analysis requires that the researcher analyzes and interpret data extracted from the documents (Bowen, 2009). In this thesis, the data extracted from the selected 
documents is analyzed within the theoretical framework informing this thesis. While triangulation of methods and data is often preferred when conducing document analysis, document analysis may be utilized as a stand -alone method as it is employed in this thesis.

\section{The function of the selected documents}

The function of documents selected for analysis is important to consider in social research, as an analysis of how documents are used and for what purposes they were produced and published by the author are important facts that can provide valuable meaning and understanding to a study using document analysis (Coffey, 2013). The documents included in this thesis are all published by actors who have a direct stake in eighter Aarhus smart city vision and development, or Denmark smart city interests. This does limit the scope of the analysis, which merely provide a one-sided point of view of Aarhus smart city approach. Moreover, as the documents are official visions and presentations produced by professionals committed to presenting Aarhus in line with its smart city goals, further elaboration on features, conditions or critical personal accounts must be considered beyond the scope of this analysis.

\section{Language}

The documents included in this thesis are written and published in English and Danish depending on the documents. The English version is always selected first if available, however, not all documents are published in English and in such case, the Danish versions has been selected and included in the thesis. In cases where a Danish version is the only available source, passages extracted from the documents has been translated into English and used directly in the analysis.

\subsection{Document selection and presentation}

The selection of documents included in this study is mainly based on the criterions by whom is the document produced and published, and what geographical area does the document target. Moreover, documents have been selected based on their connection to smart city activities in 
Aarhus, and in Denmark as a whole. The following table, show the documents selected and included in the analysis of this thesis. The documents have been structured according to document title, Document type/classification, Theme/category, and Source/publisher. Furthermore, the documents all relate to Aarhus's smart city activities and vision to some degree, but while some documents are published by Aarhus, some are published by other actors. These documents are marked as primary and secondary in both the table, and when referenced in the analysis.

\begin{tabular}{|c|c|c|c|}
\hline Document title & $\begin{array}{l}\text { Document } \\
\text { type/classification }\end{array}$ & Theme/category & Source/publisher \\
\hline \multicolumn{4}{|l|}{ Primary documents } \\
\hline $\begin{array}{l}\text { Smart Aarhus: a } \\
\text { Scandinavian third way }\end{array}$ & $\begin{array}{l}\text { Vision/strategy } \\
\text { Primary document }\end{array}$ & $\begin{array}{l}\text { Smart city vision/ } \\
\text { partnerships } \\
\text { Scale: City, Aarhus }\end{array}$ & $\begin{array}{l}\text { Smart Aarhus - Aarhus } \\
\text { municipality's smart city } \\
\text { initiative }\end{array}$ \\
\hline $\begin{array}{l}\text { Et attraktivt og } \\
\text { bæredygtigt Aarhus for } \\
\text { alle - Pejlemærker } 2019 \\
-2021\end{array}$ & $\begin{array}{l}\text { Strategy } \\
\text { Primary document }\end{array}$ & $\begin{array}{l}\text { City development/ } \\
\text { sustainability } \\
\text { /Smart city } \\
\text { Scale: City, Aarhus }\end{array}$ & $\begin{array}{l}\text { Teknik og miljø, Aarhus } \\
\text { Municipality }\end{array}$ \\
\hline $\begin{array}{l}\text { On the way to fossil } \\
\text { freedom - a climate } \\
\text { strategy for Aarhus }\end{array}$ & $\begin{array}{l}\text { Vision } \\
\text { Primary document }\end{array}$ & $\begin{array}{l}\text { Sustainable } \\
\text { development }\end{array}$ & The city of Aarhus \\
\hline $\begin{array}{l}\text { Udviklingsplan - } \\
\text { Lisbjerg en del af } \\
\text { Aarhus midt i } \\
\text { landskabet } \\
(2018)\end{array}$ & $\begin{array}{l}\text { Strategy } \\
\text { Primary document }\end{array}$ & $\begin{array}{l}\text { Masterplan for } \\
\text { urban Development } \\
\text { Scale: City, Aarhus }\end{array}$ & $\begin{array}{l}\text { Teknik og miljø, Aarhus } \\
\text { Municipality }\end{array}$ \\
\hline $\begin{array}{l}\text { Smart city i Aarhus - } \\
\text { Byens drift og } \\
\text { bygningsdrift } \\
(2018)\end{array}$ & $\begin{array}{l}\text { Power point } \\
\text { presentation }\end{array}$ & $\begin{array}{l}\text { Smart city } \\
\text { strategy/vision }\end{array}$ & $\begin{array}{l}\text { Teknik og miljø, Aarhus } \\
\text { Municipality }\end{array}$ \\
\hline $\begin{array}{l}\text { Sådan arbejder Aarhus } \\
\text { kommune med smart } \\
\text { city } \\
(2016)\end{array}$ & $\begin{array}{l}\text { Power point } \\
\text { presentation } \\
\text { Primary source }\end{array}$ & $\begin{array}{l}\text { Smart city } \\
\text { strategy/vision } \\
\text { Scale: City, Aarhus }\end{array}$ & $\begin{array}{l}\text { Teknik og miljø, Aarhus } \\
\text { Municipality }\end{array}$ \\
\hline \multicolumn{4}{|l|}{ Secondary documents } \\
\hline $\begin{array}{l}\text { Danish Smart Cities: } \\
\text { sustainable living in an } \\
\text { urban world }\end{array}$ & $\begin{array}{l}\text { Report } \\
\text { Secondary } \\
\text { document }\end{array}$ & $\begin{array}{l}\text { Partnerships/ smart } \\
\text { cities/ smart city } \\
\text { initiatives } \\
\text { Scale: National }\end{array}$ & $\begin{array}{l}\text { Copenhagen Capacity- A part of } \\
\text { Copenhagen Cleantech Cluster }\end{array}$ \\
\hline $\begin{array}{l}\text { Growing smart cities in } \\
\text { Denmark: digital } \\
\text { improvement and } \\
\text { national prosperity }\end{array}$ & Report & $\begin{array}{l}\text { Smart city/ } \\
\text { innovation \& } \\
\text { prosperity }\end{array}$ & $\begin{array}{l}\text { By: Arup } \\
\text { Commissioned by: Ministry of } \\
\text { foreign affairs of Denmark, } \\
\text { invest in Denmark. }\end{array}$ \\
\hline
\end{tabular}




\begin{tabular}{|c|c|c|c|}
\hline & $\begin{array}{l}\text { Secondary } \\
\text { document }\end{array}$ & Scale: National & $\begin{array}{l}\text { Financing partners/Steering } \\
\text { committee: Danish Business } \\
\text { Authority, The Capital region of } \\
\text { Denmark, city of Copenhagen, } \\
\text { Aarhus university, Gate } 21\end{array}$ \\
\hline $\begin{array}{l}\text { Smart Cities: creating } \\
\text { livable, sustainable, and } \\
\text { prosperous societies } \\
\text { (May 2018) }\end{array}$ & $\begin{array}{l}\text { Report } \\
\text { Secondary } \\
\text { document }\end{array}$ & $\begin{array}{l}\text { Smart city / } \\
\text { partnerships/ } \\
\text { international/ } \\
\text { sustainability } \\
\text { Scale: National/ } \\
\text { International }\end{array}$ & $\begin{array}{l}\text { State of Green: working to } \\
\text { facilitate relations between } \\
\text { Danish and international } \\
\text { stakeholders. }\end{array}$ \\
\hline $\begin{array}{l}\text { Vækst - og } \\
\text { jobpotentialer for smart } \\
\text { city i Danmark: en } \\
\text { analyse af danske smart } \\
\text { city - virksomheder } \\
\varnothing \text { konomiske aktivitet og } \\
\text { beskæftigelse (2019) }\end{array}$ & $\begin{array}{l}\text { Report } \\
\text { Secondary } \\
\text { document }\end{array}$ & $\begin{array}{l}\text { Job } \\
\text { creation/economic } \\
\text { growth/smart city } \\
\text { activities } \\
\text { Scale: National }\end{array}$ & $\begin{array}{l}\text { Damvad analytics for smart city } \\
\text { cluster Denmark in collaboration } \\
\text { with Dansk Erhverv, BloxHub, } \\
\text { state of green and Gate } 21\end{array}$ \\
\hline $\begin{array}{l}\text { Focus Denmark, } \\
\text { Business and Beyond } \\
2015 \\
\text { (+24-page special report } \\
\text { on smart cities p.54) }\end{array}$ & $\begin{array}{l}\text { Denmark's official } \\
\text { English language } \\
\text { Magazine } \\
\text { Secondary } \\
\text { document }\end{array}$ & $\begin{array}{l}\text { Smart City } \\
\text { Scale: } \\
\text { national/internation } \\
\text { al outlook }\end{array}$ & $\begin{array}{l}\text { Ministry of foreign affairs of } \\
\text { Denmark } \\
\text { Um.dk/en }\end{array}$ \\
\hline
\end{tabular}

\subsection{Coding of documents}

To codify in qualitative research, is to arrange information in systematic orders, categories, and classifications. Thus, data coding is the process of grouping, linking and segregating data into categories to recognize patterns and elicit and develop meaning (Saldaña, 2009) Acknowledging that preexisting theories drive the coding process is important (ibid). While many forms of coding may be applied to qualitative document analysis, the method of lumper coding has been used in this study, as the approach allow for the researcher to conduct document analysis in a way that target the essence of the researched material in the initial phases of the coding process, while still making room for further detailed sub-coding later in the process (ibid). The lumping approach is beneficial when working with large quantities of documents, as it allows the researcher to include more materials (ibid). The coding phase that the research process of this thesis has followed, is the interactive process of analyzing documents which entails the 1) skimming the documents 2) reading 
the documents more closely 3) interpret, code and compare 4) Thematic analysis that allow for comparison and finding of patterns across documents. The coding phase has led to identify the codes listed in the table, which has later been lumped into the five categories presented in the following table:

\begin{tabular}{|c|c|c|c|c|}
\hline $\begin{array}{c}\text { One. } \\
\text { Smart city } \\
\text { approach }\end{array}$ & $\begin{array}{c}\text { Two. } \\
\text { Economic/business } \\
\text { dimension }\end{array}$ & $\begin{array}{c}\text { Three. } \\
\text { Sustainability }\end{array}$ & $\begin{array}{c}\text { Four. } \\
\text { Partnerships and } \\
\text { networks }\end{array}$ & $\begin{array}{c}\text { Five. } \\
\text { Practice/ } \\
\text { Implementation } \\
\text { level }\end{array}$ \\
\hline $\begin{array}{l}\text { - Offering an } \\
\text { alternative } \\
\text { approach } \\
\text { - Unique } \\
\text { Scandinavian smart } \\
\text { city model } \\
\text { - Democracy } \\
\text { oriented approach } \\
\text { - Holistic approach } \\
\text { - Development } \\
\text { notion } \\
\text { - Social approach } \\
\text { - Model for } \\
\text { achieving goals } \\
\text { - No fixed strategy } \\
\text { but vision }\end{array}$ & $\begin{array}{l}\text { - Economic growth } \\
\text { equals sustainable } \\
\text { development } \\
\text { - Job creation } \\
\text { - Investment } \\
\text { - Response to a } \\
\text { lack of resources } \\
\text { - Projects with clear } \\
\text { business potential } \\
\text { - Stimulate growth } \\
\text { - Prosperity } \\
\text { - Efficiency and } \\
\text { streamlining } \\
\text { - self- promotion } \\
\text {-Attractiveness } \\
\text { - Promote/create } \\
\text { solutions for export } \\
\text { - International role } \\
\text { model }\end{array}$ & $\begin{array}{l}\text {-Sustainable } \\
\text { development } \\
\text { - Solution to } \\
\text { environmental } \\
\text { challenges } \\
\text { - Model for } \\
\text { achieving goals } \\
\text {-Holistic model } \\
\text { - Sustainable } \\
\text { urban innovation } \\
\text { - Sustainable } \\
\text { mobility } \\
\text { - Green and blue } \\
\text { city goals } \\
\text { - social } \\
\text { sustainability }\end{array}$ & $\begin{array}{l}\text { - Stakeholders } \\
\text { - Cross sector } \\
\text { Partnerships } \\
\text { - Beyond national } \\
\text { boarders } \\
\text { - Smart cities } \\
\text { networks } \\
\text { - Competitive edge } \\
\text { - Private public } \\
\text { partnerships } \\
\text {-cities provide the } \\
\text { framework for } \\
\text { citizens and private } \\
\text { actors to work }\end{array}$ & $\begin{array}{l}\text { - Piolet projects } \\
\text { - Scalable projects } \\
\text { - Testing scale 1:1 } \\
\text { - Living labs/urban } \\
\text { testbeds } \\
\text { - Smart living } \\
\text { - Social events and } \\
\text { initiatives } \\
\text { - Smart mobility } \\
\text { testing } \\
\text {-Consulting on new } \\
\text { developments }\end{array}$ \\
\hline
\end{tabular}

\subsection{Selection of Case}

Aarhus is Denmark's second largest city with a population of 352.739 (first quarter of 2021) (Aarhus i tal, 2021). Aarhus has been chosen as a case study for this thesis, as it is home to one of Denmark's most comprehensive smart city initiatives. Aarhus's smart city initiative is named Smart Aarhus, and it is the main driver behind various smart city activities, initiatives, and partnerships in Aarhus. Smart Aarhus is furthermore engaged with both private and public sector collaboration, and it is working with partners both nationally and internationally (smart.aarhus.dk, 2021). In addition to being one of Denmark's leading smart city actors, Aarhus has also made itself knowns to approach the smart city concept in its own unique and alternative way. According to Aarhus, their smart city initiative Smart Aarhus is known internationally for being a leading example of a 
"Scandinavian third way" to approaching the smart city concept. The self-proclaimed third way approach to the concept is conveyed as based on involvement of users, citizens and partners, and both economic, social, and environmental aspects are said to play a key role in the approach (businessaarhus.dk, 2020).

\section{Theoretical Framework}

Theis part of the thesis is dedicated to presenting the theoretical framework that inform the study. The chapter is divided into three main parts: Introduction to the Smart City, Sustainable urban development, and the Neoliberal era and the urban. The theory presented in the three chapters will be used in the analysis and discussion parts of the thesis.

\subsection{Introduction to the smart city}

During the past decade, a growing body of literature criticizing the smart city has been published. While observers of the smart city project and parts of academia are arguing against the smart city as a guiding concept for urban development, the concept has continued to spread, and it has gained momentum in cities all over the world. The aim of this section is to describe this development, and thereby provide a greater understanding of the smart city as an emerging project and concept.

The smart city concept first emerged in the 2010s and has been gaining momentum ever since. While the smart city as a concept is relatively new, it is born out of a long history of competing interests and urban planning goals. Throughout urban history, there has been a strong tradition for applying technocratic solutions to urban policy challenges. Urban history has shown that large-scale urban interventions are controversial regardless of context, and that they provoke strong opinions and feelings about how cities are ideally planned, for whom they are planned, and by whom they are planned. In the mid-twentieth century, urban planning was largely dominated by urban renewal programs that paved the way for multilane highways and other large scale technocratic urban solutions. Over time, dramatic large-scale urban interventions repeatedly provoked strong responses by people opposing to dramatic changes driven by top-down approaches to urban planning. In many 
cases, the controversies have sparked disagreements and discussions over the right to the city, and provoked mistrust between urban dwellers and decision makers. These historical events can to some extent be understood as paving the way for a "after the planner" attitude adopted by those arguing that urban planning should start with investment in places and people, and be defined by communities themselves, in oppose to the top-down approach that planners were often accused of practicing (Clark, 2020). As today's smart city project ultimately deals with urban technological solutions mostly driven by top-down approaches to planning, smart city advocates and actors has always been concerned with finding ways of communicating their grand visions in ways that would not provoke and reawake the old "after the planner" scenario. The great awareness of previous times, has guided smart city advocates to practice careful communication and promotion of the concept, and up until now, the approach has proven effective, as the smart city concept has emerged steadily and gained momentum without triggering much resistance (ibid)

As we now find ourselves in an age defined by rapid urbanization and a climate crisis largely generated by human behavior and consumption largely practiced in urban context, cities may to some extent be seen as the ground zero of our times problems (Dawson, 2017). Finding solutions to urban challenges and rethinking the ways we organize and plan our cities is now top priority for urban decision makers across the world, and the smart city concept has thus emerged as a grand solution to these challenges. The smart city is most often described and portrayed as a complete fixit-all solution to a wide range of urban problems. The smart city concept as a solution, claim to be key to solving various urban problems, and the smart city has largely been constructed as a solution to a variety of urban issues (Hollands, 2013) During the last decades, smart technologies has been introduced in cities all over the world, and in an European, American and Scandinavian context, smart initiatives implemented in cities has become common practice in many places. In parts of the Asian and Arab world, the smart city project has been taken to the next level, and entire newly constructed cities has been based on smart city technologies and principals (Hollands, 2013). However, while ambitious smart city projects like Masdar in Abu Dhabi and South Korean smart city project Songdo are based on grand smart city visions, the projects have not yet proven successful as well functioning cities and continue to function mainly as showcasing cities for smart technologies (Lisdorf, 2020).

The reasons for the smart city concepts success in gaining momentum globally are many. However, among the many explanations, two obvious reasons for the smart cities' success can be emphasized as crucial. First reason is due to the lack of alternative narratives for urban innovation, as the world 
need solutions, the smart city concept fulfils this necessity. The second reason can be ascribed to the concepts ability to exist as discrete urban projects, and therefor do not emerge as largescale urban interventions (Clark, 2020).

Even though the smart city concept is often referred to, and spoken about, as a fixed concept, the smart city concept various depending on context. While the smart city as a concept is fragmented, similarities, common traits, areas of application and practices can be found across different contexts, and the follow table show the areas of application where smart technology is most often applied:

\begin{tabular}{|l|l|}
\hline Smart city technologies: areas of application \\
\hline Health & $\begin{array}{l}\text { Smart technology for monitoring cities air quality } \\
\text { Smart technologies may help understand cities and citizens individual needs. }\end{array}$ \\
\hline Safety & $\begin{array}{l}\text { Disasters: smart city technology may optimize respond time by fire departments and } \\
\text { ambulances. Also, cities may use smart technology in mapping, understanding, and } \\
\text { preparing for terrorism, natural disasters, and other large events. } \\
\text { Crime: Surveillance, detection systems, body cams etc. }\end{array}$ \\
\hline Mobility & $\begin{array}{l}\text { Public transit: Optimization of public transit flows and the use of smart } \\
\text { technologies in predicting maintenance of public transportation. } \\
\text { Private transit: Traffic regulation and application of smart tech solutions to tackle } \\
\text { traffic congestion. }\end{array}$ \\
\hline Utilities & $\begin{array}{l}\text { Water: Minimizing water waste with leakage control and smart meters } \\
\text { Energy: lowering energy use by adopting smart technologies such as smart lightning } \\
\text { solutions } \\
\text { Waste: using smart technologies for optimizing waste collection and minimize } \\
\text { resources needed for handling waste }\end{array}$ \\
\hline
\end{tabular}

(Tabel one: based on Lisdorf, 2020, pp. 14-17)

In addition to the importance of understanding how smart technologies are applied in the urban landscape, a crucial part of understanding the smart city concept, is to recognize the actors involved with shaping and promoting smart cities and smart technology. The following table show the smart city actors that are, broadly speaking, engaged in shaping and promoting the smart city project:

\begin{tabular}{|l|l|}
\hline \multicolumn{2}{|l|}{ Actors engaged with shaping, promoting, and consuming the smart city } \\
\hline Individuals & $\begin{array}{l}\text { Residents: permanent residents, concerned with the day-to-day } \\
\text { functioning/operation of infrastructure and city services } \\
\text { Visitors: mainly tourist who are concerned with transportation, mobility } \\
\text { charging stations, access to Wi-Fi } \\
\text { Civic activists: taking part in shaping the smart city and smart city solutions }\end{array}$ \\
\hline
\end{tabular}




\begin{tabular}{|l|l|}
\hline Businesses & $\begin{array}{l}\text { Driving many key urban functions in the smart city. Engaged with local } \\
\text { businesses, in tech experimentation etc. }\end{array}$ \\
\hline Vendors & $\begin{array}{l}\text { Hardware Vendors: Hardware is often attached to new implementation } \\
\text { scenarios. In general, for those selling hardware, the motivation is to sell units } \\
\text { that work both long and short term. } \\
\text { Software vendors: aiming towards implanting their software as long-term } \\
\text { solutions and making profit via fees for support, subscriptions, license etc. } \\
\text { often offering platform solutions. } \\
\text { System integrators: they create all-inclusive discrete solutions that can work } \\
\text { from end to end. They often work on project-based contracts. }\end{array}$ \\
\hline Government & $\begin{array}{l}\text { National: Depending on national context, in EU and US, national level is } \\
\text { mostly involved in creating incentives for working with smart city } \\
\text { concept/technologies. national level may grant resources for research and } \\
\text { development. } \\
\text { Regional: Depending on context, there may collaboration between the } \\
\text { common interests at local and regional levels. } \\
\text { Local: The city itself. Concerned with creating smart city progress and } \\
\text { showing results. The most important level for the smart cities project. }\end{array}$ \\
\hline Researchers & $\begin{array}{l}\text { Universities: Conducting research, working with projects and partnerships, } \\
\text { providing student Internships, generating revenue through paid research, and } \\
\text { help funding labs and staff through grants. } \\
\text { Private research: Think tanks and such (often political), producing reports } \\
\text { and research that is often distributed via media etc. } \\
\text { Independent research: Grassroot science, comparable to citizen activists }\end{array}$ \\
\hline Organizations & $\begin{array}{l}\text { Supranational organizations: develop policies and support research } \\
\text { financially (the United Nations, world bank etc.) } \\
\text { Nongovernmental organizations: Not backed by nations. Often, they are } \\
\text { devoted to selected topics such as energy, clean tech etc. they also fund } \\
\text { research and produce knowledge. } \\
\text { Philanthropies: often sponsoring smart city projects with grants etc. }\end{array}$ \\
\hline
\end{tabular}

(Tabel two: based on Lisdorf, 2020, pp. 8-13)

As shown in the tables, the smart cities project as it has evolved up until now, show a fragmented picture of a significant number of smart city actors involved in the project. Moreover, smart city actors and technologies are found to be targeting various areas of application in the urban. Among the many actors, stakeholders and smart city advocates engaged in the smart city, the corporate world is a rather dominant driver and shaping force of the concept. While the corporate side to the smart city concept will be dealt with later, for now, it is worth noting that the corporate involvement in smart city project, play a significant role in present days smart cities. 


\subsubsection{Urban living labs and testbeds}

The concept of urban living labs and testbeds are often associated with the smart city concept. As cities are looking for new and alternative ways of tackling the challenges related to rapid urbanization and climate change, urban test labs offer a new way of testing and developing urban solutions and smart city technologies. Urban living labs and testbeds are emerging in cities all over the world, and they have become a widespread and common method for testing new solutions in scale 1:1. The urban living labs are most often established as physical demonstration and test facilities, but they do however differ in method and focus, and they do therefore exist in multiple ways in the urban. While urban livings labs often have their own unique features and focal points, the basic idea behind the concept, is the aim to deliver urban sites for learning, innovating, cocreating, and developing new solutions. Moreover, the sites are often seen as places where public and private partnerships can flourish and where new cross -sector partnerships are given the ideal conditions for creating leading solutions (Marvin, et al., 2018). Though urban living labs and testbeds are no new feature in the urban environment, systematic learning about the labs has yet to be achieved and the amount of research about the value, effectiveness and real impact of the method is limited. According to research, urban living labs has been developed as a response to mainly three sets of urban conditions and challenges namely, as a reaction the world's climate and sustainability crisis, as a response to a lack of success with large-scale reorganizing of the urban, and as a consequence of a general rise in number of actors interested in experimenting with urban development and living (ibid). The technique that urban living labs are inspired by is not new, and it has in fact been an important part of the corporate world long before living labs became urban. The corporate living lab method and techniques were originally designed to help accelerate innovation in the tech industry, where the laboratory practices were used as an efficient and cost-effective way of including consumers in innovation process such as prototyping of products and services. The fact that cities are engaging with corporate methods in city planning is interesting, as it indicates a shift in modern urban planning towards greater interest in exploring new mode of experimentation and techniques that are not traditionally utilized in conventional city planning strategies. Furthermore, the shift indicates an interest in seeking out potential ways of becoming inspired by, and work together with, the corporate world. The corporate world has had a great influence on how living labs has evolved in an urban context as they since the financial crisis in 2008/2009 has targeted the urban and pursued cities as a new potential market for developing, testing, and selling products. In 
addition to corporate involvement, urban living labs also represent another urban trend, which is the great involvement of actors not traditionally known to be concerned with the urban, and academics across disciplines and various NGO's and grassroot actors are now engaging in the urban through living lab activities (Marvin, et al., 2018).

As mentioned, urban living labs exist in various forms, and they are created with the aim of fulfilling different purposes, while also addressing various urban challenges. However, overall objectives such as urban sustainability, climate adaptation, and smart technologies often defines living lab activities. Urban living labs are constantly innovating and trying our new smart city technologies (Marvin, et al., 2018). Moreover, testing of ways to improve democratic engagement and empowerment of consumers is often communicated as a goal for living labs, but research has found, that these living labs most often practice market-oriented decision making, automation and therefore resample techno- economic fixes, that can accelerate and intensify social inequalities. However, if urban living labs are handled with a bottom-up approach, emphasizing citizen participation, the urban living labs approach can represent a means to drive holistic changes (Marvin, et al., 2018).

\subsubsection{Uneven innovation}

Even though the smart city concept is gaining more momentum every day, a growing body of critical literature questioning and criticizing the smart city concept, its advocates and practices is published. Among some of the key points of critique raised by urban scholars, is the argument that the smart city concept is a driver of inequities, as it neglects social aspects of the urban. A great concern pointed to by urban scholars, is the fact that the smart cities project remains in complete absence of any type of power analysis. The overall argument is that whenever you introduce technologies to the city fabric, technology will drive changes and reorganize power relations between industries, government, citizens, public institutions - and even between city and nation. Even though many smart city technologies should be viewed as disruptive and drivers of great societal change, smart technologies are often accepted as politically neutral (Clark, 2020).

The technologies that the smart city is promoting, and seek to deploy, are not necessarily problematic within themselves, it is however pointed to by urban scholars, that the power balance between the tech industry and the public sector is often problematic. In many cases, despite arguing 
that regulations carried out by the public sector is pointless and hinders innovation, the smart cities industry manage to get public subsidies for their projects and development of smart technologies. Moreover, the smart cities industry often succeeds in avoiding assessments and evaluations of their solutions and approaches. The passive role in terms of setting up rules and boundaries that the public sector tends to take, is by far one of the greatest concerns expressed by researchers and observers of the smart city project. It is often the case, that the public sector is stepping back and allowing both places and people to be used for urban testing and experimenting with technologies. This is however problematic, as smart city advocates tend to disregard pattern of inequalities that they may create, since they are all too often preoccupied with experimenting and building smart technologies (Clark, 2020).

\subsection{Sustainable urban development}

As cities all over the world has declared sustainable development as an established goal. Research and discussions around how to create sustainable cities has come to dominate academic research, everyday conversation, and urban policy thinking. Even though sustainability is often spoken of and referred to as a fixed concept, sustainability as a concept is far from fixed and due to being use in various contexts and by numerous actors, understandings of sustainability vary greatly depending on context (Mikulak, 2010). The ways in which sustainability is understood, interpreted, and practiced in the $21^{\text {st }}$ century has evolved from decades defined by shifting emphasis on the importance of various environmental questions and different understandings of the relationship between human and nature. Broadly speaking, questions about environmental preservation has evolved from being centered around the 60ties rejection of a consumer society, to our times vision of sustainable development. While understandings of sustainability have changed during the past decades, unique to the way sustainability is understood in present time, is the association with det concept of development, and thus referred to as sustainable development. The present dominating understanding of sustainable development can be traced back to the Brundtland report which was first published in 1987. For the first time in human history, with the publication of the report, the idea that the two concepts of sustainability and development could be merged into one holistic approach, and realized at once, was presented to the public (Ibid). Additionally, with the publication of the Brundtland report also came a new understanding of the planetary environmental crisis that planet earth is faced with, and on top of that, the publication sparked a growing awareness of 
globalization and global interconnectedness. While a rather gloomy picture of the environmental state of planet earth was painted, the overall message was that we, with human intelligence, innovative thinking, and ability to engineer and shape our environment, can succeed in adopting planet earth to fit human needs, while caring for the environment and ensure economic growth (ibid). While the concept was radical when presented, time has shown, that the concept has managed to gain momentum in all parts of the world, and it has emerged as a central part of conventional policy thinking in the $21^{\text {st }}$ century (Finco \& Nijkamp, 2001).

One of the fundamental changes in how we understand the relationship between human, nature and the environment is the way capitalism and nature is perceived as mergeable. Capitalism and nature have evolved from being understood as contradicting and working against each other, to now being understood as mergeable and supporting of each other. Mikulak (2010) defines this fundamental shift as the economic turn and goes on with arguing that the idea that capitalism and nature can be treated as equally important within current societal and global structures is misleading. With the economic turn and the new paradigm of green economy, economic interests and nature should be perceived as equals and equally important, however, what is often the case, is that nature is assessed through economic logic, which rarely lead to outcomes favorable to the natural environment (Mikulak, 2010). Moreover, in his influential study of politics of environmental discourse from 1997, Maarten Hajar (1997) describes how we now find ourselves in the current age of ecological modernization. Unique to this age, is the belief that the needs of nature to survive and strive, can be met within the present capitalist system. Ecological modernization strives as a dominating understanding and approach, as it provides answers to the climate and environmental crisis we face. In oppose to previous understandings, ecological modernization points to societal restructuring as the overarching answer to our environmental problems, and thereby provide an optimistic solutionoriented approach that emerge as a stark opposite to previous doomsday views of environmental challenges (Hajer, 1997).

While various approaches to sustainability in an urban context have been, and continue to be, developed, discussed, and proposed, there exist an overwhelming consensus around accepting the concept of sustainable development as necessary for urban development in the $21^{\text {st }}$ century, and urban policies have been formed and shaped along the lines of ecological modernizations understating of the relationship between capitalism and the environment. During the past decade, a 
broad consensus about two topics has emerged across sectors and disciplines. The first one is that sustainability is achievable for cities, and that it may be achieved for all cities if the right initiatives and approaches are adopted. Second is the belief that urban sustainability may be achieved without compromising on economic, social, or environmental aspects. In fact, social and environmental sustainability and continuous urban growth is viewed as mergeable and achievable at once, if all urban actors come together and find common ground in a collective holistic approach to urban development. This understating is regularly criticized and challenged by some parts of academia, whose scholar's express skepticism about realizing the vision in present urban context. Among some of the frequently referenced urban scholars challenging the holistic sustainable development approach is Scott Campbell (2016), who, with is planner's triangle, has

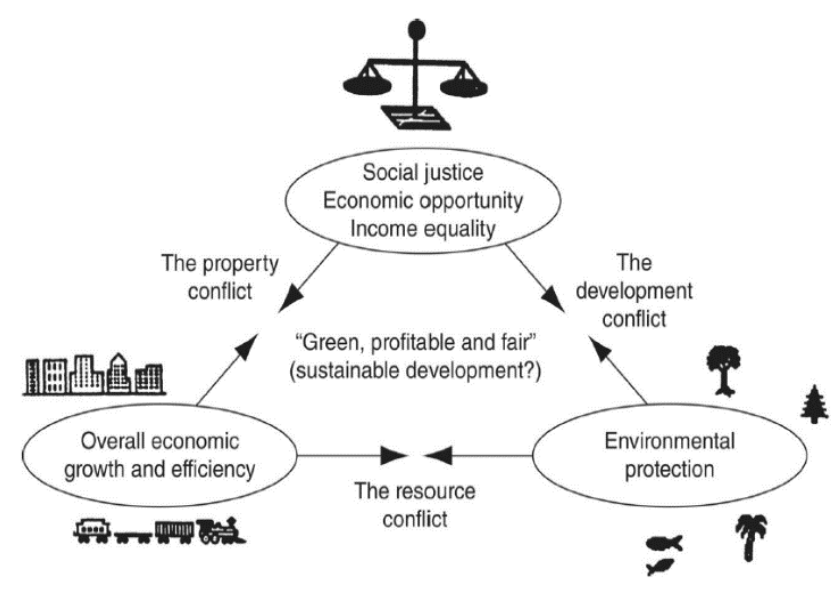

(Figure one: Planners Triangle, Scott Campbell 2016) visualized the competing urban interests hindering the sustainable city vision in being realized as easily as often perceived. Campbell is pointing to three primary interests namely, the economic, social, and environmental interests that has, up until now, proven to most often be competing opposites, rather than mergeable interests and conditions (Campbell, 2016). While competing interests may be one of the great factors hindering cities from becoming sustainable, the urban conditions of the $21^{\text {st }}$ century are amplifying the challenges of sustainable development. Conditions like rapid population growth, resources scarcity in many urban areas, growing consumption and mobility levels continue to challenge the actual realization of sustainable cities (Finco \& Nijkamp, 2001). The dominating and widely accepted vision of sustainable urban development is based on the recognition that, in order for cites to succeed with sustainable development, collective action and holistic approaches to urban development is vital for the success of their efforts. Urban sustainability policies must thus be formed to fit the fragmented landscape of urban interests, needs and actors that produce a multidimensional complexity in urban sustainable planning and development (Finco \& Nijkamp, 2001).

Even though some urban observers and scholars are questioning to what extend it is possible to achieve entirely sustainable cities, it is clear, that the sustainable development paradigm is dominating urban development in present time. Studying the topic from an urban policy perspective 
it is evident, that one must understand sustainable urban development along the lines of ecological modernization, as it is very much guiding urban policy decisions in cities all over the world. Moreover, spurred by the publication of the Brundtland report, the emerging global awareness of the 1980ties, drew attention to the urgent need for collective global action, which started a new era were local urban conditions became a concern of global actors. In present time, global organizations has become increasingly engaged with pushing local sustainable urban agendas, and actors like the United Nations is formulating and promoting urban development advise and strategies, as those first published with the global and local Agenda 21 (Unitd Nations, 1992), the United Nations 17 SDG's with goal 11 emphasizing the need for sustainable cities (United Nations, 2020), and more recently, UN Habitats world cities report 2020 on the value of sustainable urbanization (UN-Habitat, 2020). The reports are all examples of work by international actors who seek to influence urban policy making and a sustainable development agenda. As the United Nations is highly engaged with the sustainable development agenda, they also advise cities on smart technologies and sustainable development as they emphasize that depending on the local context, smart city technologies can we viewed as solutions to various urban problems related to sustainability and the environment. However, according to the UN Habitat 2020 report on the value of sustainable urbanization, det current smart city rhetoric often do not reflect reality. The report argue that the current smart city is most often we led by private technology firms, who apply a top-down approach that rarely promote a social and inclusive approach to urbanization, and thereby fail to live up to the smart city as a model that may lead to sustainable urban development (UN-Habitat, 2020).

\subsection{The neoliberal era and the urban}

The neoliberal ideology is first and foremost concerned with questions about liberty, free market capitalism, and economic liberalism. As neoliberalism has evolved, there has been published numerous studies aimed at explaining and understanding how the urban has changed during the neoliberal era, and how the policies associated with neoliberalism, has affected urban conditions and development. This theory section is aimed at introducing the neoliberal city and describe urban conditions during the neoliberal era.

While numerous researchers have studied urban development and change during the neoliberal era, some of the most referenced research has been produced by David Harvey who, among other 
things, has studied capitalism and urban entrepreneurialism (Harvey, 1989) and, more specifically the urban under neoliberalism (Harvey, 2007; Harvey, 2012 ). According to Harvey, the urban has gone through significant changes during the neoliberal era. Following neoliberal ideology, many cities has adopted an entrepreneurial mindset which has led cities to be run like private business, favoring liberalism and a free-market approach. Cities has become increasingly open for business and has allowed the private sector to gain momentum in urban development. As cities has adopted this approach, the global market logic that defines the neoliberal era, has had a great influence on the development of cities. As capital has been freed globally, global capital investments have shaped the urban property market in countries all over the world (Harvey, 2007). Moreover, interurban competition has emerged as an urban phenomenon, and cities has widely adopted competitive mindsets and immersed themselves in the battle for capital investment in ways not previously known to the urban. The overall logic behind allowing the private sector to have an increasingly bigger say in urban development, is the reasoning that, to truly prosper and grow the urban economy, cities must invite private actors in, and run their cites with a corporate mindset (Harvey, 2007). Whereas policy making in cities previously depended on institutions and officials, in the neoliberal city, these processes are increasingly dependent on private actors and corporations. Moreover, during the neoliberal era, governments has adopted and implemented neoliberal austerity strategies that has fundamentally changed societal structures (Mayer, 2016). For the urban, austerity strategies have led to an extensive privatization of public services and infrastructure traditionally known to be managed by the public sector. As the public sector is increasingly outsourcing and subcontracting public services and infrastructure, urban governments has been observed to gradually transform themselves into service purchasers and thus leaving their former roles as urban service suppliers (Mayer, 2016). Even though smart city advocates rarely engage in discussions about urban governance and policies, the extensive privatization (and subcontracting) processes that cities has undergone during the neoliberal era, is found to drive the implementation of smart technologies, as well as the realization of smart city visions. While it varies from city to city how many public services they outsource, most cities are subcontracting business services in the $21^{\text {st }}$ century. Among the most used outsourcing practices for cities, is the outsourcing to private consulting companies that work with strategies tailored to make profit. These companies are allowed a powerful position in the development of cities. Furthermore, in many cities, essential services such as waste management, transportation and public health services are subcontracted to private actors (Clark, 2020). 
The perspective of economic geography is important to include in ones understanding of the smart city project, as the project should ultimately be interpreted as a great driver of rearrangement of resources, values, and assets in cities. The economic perspective is essential, because it provides a deeper understanding of the distribution and availability of urban assets (ibid). Even though the tech industry has traditionally been drawn to the flexibility and endless possibilities of developing products that are not bound by geography, in the 2010s, the tech industry started to show great interest in the urban as a new market opportunity (ibid). For present times cities, the tech sectors urban interest represents new prospects of growth and urban prosperity. Smartness symbolizes the opportunity to improve and develop urban areas, as investment can finance urban development. Moreover, as major cities are seen as engines for national growth, in the neoliberal era, the smart city concept is promoted and pushed has part of governments quest for growth of national economies. Neoliberal policies has led both cities and national governments to remove businesses barriers and nurture cross-sector collaboration and optimal conditions for innovating, implementing, and exporting smart technologies (Vanolo, 2014, Hollands, 2013, Grossi \& Pianezzi, 2017).

\subsubsection{The corporate smart city}

As already mentioned, the smart city concept and neoliberalism share many similarities and signature traits. In fact, the smart city project and neoliberalism may be seen as interconnected in the sense that the smart city project extents and build on to neoliberal policies such as: deregulation, privatization, and decentralization (Clark, 2020) As explained earlier, as a result of neoliberal urban policies, cities has opened up the corporate world, and the tech industry has therefore turned their attention to the urban which they are now targeting as a new market opportunity that can potentially offer large economic gains. As explained, the corporate world is increasingly involved in shaping and defining the urban in various new ways. While many actors have an interest and a stake in the smart city, research point to the corporate involvement in the smart city as a major shaping factor in current times urban development.

A significant part of how the smart city project is approached in the $21^{\text {st }}$ century is the widespread acceptance of the notion that the smart city may only be delivered successfully with significant corporate involvement. Moreover, it is broadly accepted that the corporate worlds interpretation of urban smartness, can only be achieved by combing an entrepreneurial approach to urban 
governance (Hollands, 2013). In practice, this means that examples of private business involvement in shaping the urban are found all over the world, and particularly with the smart city vision guiding the process. Definitions of the corporate smart city vision may vary depending on the context, however, broadly speaking, the vision is often a one-sided proposal of the ideal smart city model. As the smart city project has gradually gained more success among urban decision makers all over the world, critical research questions whether grand smart city projects, largely driven and financed by corporate power and money, will lead to the best results for cities. Furthermore, a great concern is raised of how inclusive and holistic an approach the corporate smart city vision will prove to be, when largely guided my private profit (Hollands, 2013).

\section{Analysis}

The next five sections of this thesis are dedicated to the analysis of the study. As presented and explained in the method part, the analysis is built around five main categories presented in the table of the section. The categories have been extracted using the lumper coding technique, resulting in the following five main groupings: One: Smart city approach, Two: Economic/business dimension, Three: Sustainability, Four: Partnerships and networks, and Five: The smart city in practice.

\section{One: Smart city approach}

The first category that the coding and lumper coding process has led to develop, is the category one dubbed smart city approach. When reading and analyzing the documents, it is evident that the documents are showing a rather fragmented and extensive number of visions and goals formulated by, and on behalf of Aarhus. In the case of Aarhus, it is striking how the city seeks to emphasize and make clearly known that they are building a smart city concept unique to Aarhus, and that they are thereby disassociating itself from how the smart city concept is interpreted and materialized elsewhere. It is directly formulated by the city as follows:

"internationally, Smart Aarhus is considered a Scandinavian third way that offers a model for city development based on the practice of stakeholder and citizen involvement, and which differs from both the more commercial American and the more centrally controlled Asian traditions. In 
addition, social, economic, and environmental sustainability play a central role in Scandinaviaand to Smart Aarhus." (Smart Aarhus, 2015, p. 6).

The excerpt clearly show that Aarhus is addressing one of the strongest critiques raised against the smart city, by offering an alternative take on the concept and clearly distancing itself from the corporate and top-down smart city approaches allegedly found in Asian and American contexts. When seeking to communicate how Aarhus approach stand out, Smart Aarhus introduce the ways in which they perceive themselves as "different" from other cities approaches. One of Aarhus key points is their great emphasis on strengthening democracy through technology. According to Smart Aarhus, one of Aarhus main goals of working with smart technologies, is their vision of how technologies can help foster democratic participation in the future development of the city (ibid, pp. 16, 42). Furthermore, Aarhus is stressing that one of the focal points of their smart city mindset, is their aim to use technology to strengthen not only citizen participation, but also strengthening collaboration and community building. In achieving this vision, they highlight an initiative named the social day, which is created with the overall aim of engaging locals across background, age, and socio-economic status, for a day of collaborative work and problem solving in the city (ibid, p. 8) The role of technology in such initiative, will be presented further later in this analysis. In addition to being presented in the primary documents included in this thesis, the approach is also found highlighted in various secondary documents such as in the following report by Arup 2016: "The smart city efforts in Aarhus, Smart Aarhus, are organized around the principles of citizen involvement and co-production" (Arup, 2016, p. 21).

In addition to the topics presented about how Smart Aarhus regard itself as representing an approach that stand out from other smart city approaches, the material published by Smart Aarhus, also show a smart city vision that is noticeably similar to what is found in cities elsewhere. Furthermore, many parts of the vision presented by Aarhus, involve themes that are usually linked to the smart city concept as informed by literature included in the theoretical framework of this study. Among these themes, is the presentation of the of the smart city concept as a problem solver approach (ibid, pp 8,10) in addition, the holistic approach that the smart city is often portrayed as, it is also articulated in Smart Aarhus's material, where the following is written: "Smart Aarhus is a digital marketplace established in order to generate value and help solve societal, environmental and economic challenges." (Smart Aarhus, 2015, p. 8). As informed by the theoretical framework, 
this perception of the smart city as a comprehensive holistic approach, is one of the most commonly found descriptions of the smart city.

\section{Two: Economic/business dimension}

In the documents selected for this thesis, a rather strong emphasis is put on the economic dimensions of the smart city, thus the second section in this analysis, is dedicated to this category.

Throughout the selected documents, the economic aspect of the smart city is mentioned numerous times, and it appears as a very central topic to Aarhus's smart city vision. As touched upon earlier in the theory section, economic aspects is not a strange topic to the smart city, and in that sense, it is not surprising that it play a key role in Aarhus smart city vision. Growth is a key topic linked to various aspects of Smart Aarhus who state that:" Smart Aarhus projects have clear business potentials and help create growth." (Smart Aarhus, 2015, p. 10). Aarhus is, in other words, saying that their smart city initiatives, activities and projects are only launched and worked on, if they can contribute to economic growth. The growth aspect of the smart city is found to be articulated on three levels, namely on both a city, regional and national level. The economic growth that Aarhus envision smart technologies will foster in the city, is addressed numerous times throughout their vision, where economic growth is communicated via the different smart city initiatives which emphasize economic growth as one of the major benefits. (Ibid, p.16, 24, 28,44). In addition to the economic growth smart technologies are believed to foster on a city level, regional and national economic growth interests are also addressed and emphasized in both primary and secondary documents:" A main task of Smart Aarhus is to promote Smart Aarhus and Smart City interests both on a local, national, and international level." (Smart Aarhus, 2015, p. 12). This quote show how the smart city initiative in Aarhus is orientating itself towards the national and international community, and thereby communicating their aim of using their smart city activities to reach beyond city borders and prosper from engaging on national and international scale.

Job creation is a theme that play a significant role in the documents selected for this analysis. As already explained, the business opportunities that the smart city is perceived to bring, play a large role in driving Aarhus smart city initiatives. As smart city activities are predicted to increase the number of local job opportunities, Aarhus smart city vision is focused on supporting and 
strengthening private tech actors through projects, and it is their declared goal to: "Strengthen the digital economy and create jobs" (Smart Aarhus, 2015, p. 10).

Another characteristic that defines both the smart city and the neoliberal city, is the great emphasis that is put on optimization and streamlining. As informed by the theory section of this thesis, during the neoliberal era, the urban has, in line with other parts of society, experienced a restructuring of societal structures and implementation of austerity measures with the aim of streamlining. This is also true for cities, which in many cases led them to evolve into service purchasers, rather than service providers. Such urban conditions are ideal for smart city actors, as an evolving new for market public service solutions merge perfectly with smart city solutions. In Aarhus, further digitalization is also perceived to be the right response to streamlining how the city is run, and the municipality stated the following in 2019: "we must use technologies to digitalize, streamline and automize our own workflows both internally within the municipality and in the interface with our partners." (Aarhus Municipality - Teknik og Miljø, 2019, p. 35). Furthermore, a few years prior to that, the municipality shared their vison in a special smart city edition published in the Ministry of Foreign Affairs of Denmark's magazine Focus, where they stated the following:

"Smart Aarhus is about getting the most out of digitization. It is a new division of tasks in the city; the public sector still participates but private companies and citizens play a larger part in delivering services traditionally provided by the public sector" (Ministry of Foreing Affairs of Denmark, 2015).

These paragraphs illustrate how the smart city concept and the neoliberal city merges perfectly, and therefore should be understood as supporting of each other, as the smart city among other things is offering what the neoliberal city needs, namely efficient and cost-effective solutions for public services.

As informed by the theoretical framework presented in the beginning of this thesis, in the neoliberal city, adopting a competitive mindset is key to success. As cities are increasingly run like private businesses that compete for investments and human talent, image, attractiveness, and selfpromotion is important. In the following extract, one among may statements relating to this topic is shown: "This leads to new business models and a region with a stronger competitive edge" (Smart 
Aarhus, 2015, p. 12) This excerpt illustrates how Aarhus has adopted a competitive mindset which is characteristic for both the neoliberal city and the smart city concept. Here, the smart city is clearly seen as a means to foster and maintain a competitive approach, in order to continuously grow economically and thereby ensure growth and prosperity. Furthermore, Aarhus has identified itself as particularly attractive due to its size, and it is clear in several parts of the published documents, that Aarhus seek to sell itself to private actors: "Aarhus has a size, that makes the city attractive for many companies who, as part of their development, wish to test new technologies and solutions in large scale.” (Aarhus Municipality - Teknik og Miljø, 2019, p. 31).

In addition to the paragraphs selected and extracted for this analysis, the very document which has been referred to numerous times throughout this analysis, represent the competitive mindset and goals that drive the implementation of the smart city vision, as it is presented as a brochure promoting the smart city vision in a way that resemble sales material normally published by private businesses.

\section{Three: Sustainability}

For Aarhus, working with sustainable development and strategies for achieving carbon neutrality is nothing new. Throughout the past decade, Aarhus municipality has developed and formulated numerous visions and strategies directing their green development. A significant part of the documents bears a resemblance to most cites approaches to sustainability and environmental challenges in present time, and Aarhus is formulating their green vision in line with the notion of holistic sustainable development advised by influential organizations like the UN etc. Moreover, as informed by the theoretical framework of this thesis, sustainable development is often linked to the smart city concept, and while sustainability plays less of a role for smart cities in some parts of the world, in a Danish context, research has found, that the smart city concept is often linked to notions of sustainable development. The holistic sustainable approach, and its dependence on smart technologies is addressed in Aarhus Climate plan 2016 -2020, where it is stated that: "Green transformation covers a number of things, including new technologies, better use of resources, more eco-friendly products, new business models and a high degree of social involvement." (City 
of Aarhus, n.d., p. 5). This statement highlights the need for technology, while also addressing the same holistic approach to city development, as emphasized in the smart city vision.

In the case of Aarhus, the sustainable development concept clearly plays a significant role in their aim towards becoming a smart city. This is visible in both the smart city vision, climate plan and activities and initiatives promoting and utilizing smart technology. In line with the environmental discourse ecological modernization presented in theoretical framework of this thesis, Aarhus is striving towards becoming a green and blue city, by deploying smart technologies to the city fabric. Trusting that cities can innovate and engineer themselves out of the current climate and sustainability crisis, Aarhus is relying on emerging and existing technologies for achieving this goal. A concrete example presented in the secondary documents selected for this thesis, is the city's use of smart technology to control water quality, as well as forecasting and predicting flooding and sewer overflows following heavy rain episodes (State of Green, 2018 , p. 15).

While technology is accepted as a grand solution, Aarhus also expresses their devotion and strong belief in the concept of sustainable development in most selected documents, where statements about sustainability is often linked to economic growth:" Smart Aarhus is a new mindset developed in order to create sustainable urban innovation and growth." (Smart Aarhus, 2015, p. 8). In this excerpt, the Smart Aarhus initiative, is highlighted as a means to encourage innovation and drive growth in the city. Furthermore, the Aarhus elaborates on the initiative further in the document as they state that:

"The climate initiative in the City of Aarhus aims at combining sustainable urban developments with economic growth. The initiative covers projects that develop solutions within energy optimization and climate adaptation, that reduce CO2 emissions, and that make the city an attractive place to live and work." (Smart Aarhus, 2015, p. 28)

Moreover, it is described how the municipality is strategically using their green city status and know how about sustainability and green technology, as a means to boost export possibilities and attract investment and talent: "By making Aarhus visible as a modern, attractive and green city for investors, companies and potential employees for local businesses, we may increase our possibilities for export of local green technology and know-how" (Aarhus Municipality - Teknik og Miljø, 2019, p. 31). These passages combined, exemplify how the city is using the smart city concept as a means to achieve sustainability in a holistic and balanced way. Relating it to the theoretical framework of this thesis, one may look to Campbell's triangle which has previously 
been presented. Following Campbell's theory, the smart city approach that is articulated by Aarhus seek to use smart technologies to do what Campbell deems a huge challenge, namely finding a solution to balancing conflicting goals, needs and aims.

While a strong belief in a holistic approach to sustainability is emphasized as a main solution, social sustainability is not formulated and described using the exact term. However, as already explained in the first section of this analysis, throughout the documents, Aarhus's smart city approach is expressing a concerned with conditions related to the social city fabric. While Aarhus is not found to express social sustainability in its exact terms, initiatives related to social aspects are found to be expressed via the different smart city projects in the city. Examples are the social day, internet week Denmark, City pulse and in the Gjellerup Masterplan project (Smart Aarhus, 2016, pp. 18, 14, 26, 36 )

\section{Four: Partnerships and networks}

In addition to the economic aspects of the smart city which has been found to be central to Aarhus's smart city vision, a key feature of the vision is the great emphasis Aarhus put on partnerships, networks, cross-sector collaboration, and stakeholder engagement. Throughout the documents, Aarhus's smart city vision is repeatedly addressing the need for joining and engaging in partnerships and various smart city networks on both local, regional, and international level. On a local level, broad cross-sector collaboration is emphasized as a key feature of Aarhus smart city approach:

"Smart Aarhus proposes an alternative collaboration between the public and the private sector, citizens, the business community, and knowledge institutions, where we work together to make use of digital opportunities and to address challenges across existing sectors and hierarchies." (Smart Aarhus, 2015, pp. 8-9).

While Aarhus argue that they represent an alternative approach to collaboration, in the passage extracted from their vison, their approach bear resemblance to the partnership visions and strategies well known to research on smart cites. As informed by the theoretical framework of this thesis, the cross-sector partnerships are merely a unique feature that define the smart city, but rather, also a condition central to the neoliberal era (and city). Moreover, it was pointed out in the theory section, that such features, support the analysis that the neoliberal city and the smart city should in fact be 
understood as interconnected and enabling of each other. This theory is furthermore supported by the following statement:

"We need to create a new way of collaborating and creating public service that involves the public sector, citizens, and the business community. Citizens and companies must accept a higher level of responsibility." (Smart Aarhus, 2015, p. 11).

Here, three topics central to the neoliberal city and era are expressed. First, the modes of organizing society so that the public sector is increasingly interconnected with the private. Second, that the services previously managed by the public sector, are ideally outsourced to private actors and third, the neoliberal preoccupation with questions related to individualism, and the trend that more responsibility is put on the individual and not society, is also evident in the previous.

In addition to national and regional partnerships and collaboration, a key topic that is repeatedly emerging throughout most smart city literature, is the emphasis on the importance of global collaboration. It is most often declared, that for cities to truly become smart, and thereby ensure sustainable development, decisionmakers must look to the global smart city community for collaboration and inspiration. Because of this notion, many smart city actors see global collaboration as best practice. Aarhus's smart city initiative I however also found to be far from secluded, and an active and strong engagement with international partners and network organizations is communicated and presented in their vision:

"Smart Aarhus promotes national and international collaboration across cities and regions to ensure that efforts are coordinated broadly. The Smart Aarhus Secretariat takes on a leading role in coordinating activities in the Danish Smart City Network and in the Connected Smart Cities Network, which provides an international forum for smart city solutions" (Smart Aarhus, 2015, p. $6)$.

When reading this excerpt among others, it is evident that both national and international networks are considered important to Aarhus's smart city development. Furthermore, Aarhus is found to perceive itself as a leading smart city actor in national and international smart city communities. As shown in the following table, international partnerships, and organizations that Aarhus are engaging with, covers most of the globe including Scandinavia, Europe, America, Asia and Australia. 


\begin{tabular}{|c|c|c|c|}
\hline \multicolumn{4}{|c|}{ Partnerships, networks, and forums that Smart Aarhus is engaged in: } \\
\hline $\begin{array}{l}\text { Name/ } \\
\text { Type }\end{array}$ & Description of partnership & $\begin{array}{l}\text { Focus/ } \\
\text { dimension }\end{array}$ & $\begin{array}{l}\text { Partners/ } \\
\text { stakeholders }\end{array}$ \\
\hline $\begin{array}{l}\text { SCORE } \\
\text { North Sea smart } \\
\text { city partnership } \\
(2017)\end{array}$ & $\begin{array}{l}\text { Collaboration between } 9 \text { cities in the } \\
\text { North Sea region, aimed at improving } \\
\text { public services based on data-driven } \\
\text { smart solutions. Aims at reducing public } \\
\text { service coasts with } 10 \%\end{array}$ & $\begin{array}{l}\text { Partnership/ } \\
\text { smart } \\
\text { solutions for } \\
\text { public } \\
\text { services/ } \\
\text { efficiency/ } \\
\text { streamlining }\end{array}$ & $\begin{array}{l}\text { Partner cities: } \\
\text { Amsterdam, } \\
\text { Dordrecht, Hamburg, } \\
\text { Gent, Gothenburg, } \\
\text { Bergen, Bradford, } \\
\text { Aberdeen }\end{array}$ \\
\hline $\begin{array}{l}\text { IWDK Internet } \\
\text { week } \\
(2017)\end{array}$ & $\begin{array}{l}\text { Digital festival initiated by Aarhus in } \\
\text { 2014. Targeting professionals, students, } \\
\text { and private citizens in all age groups: In } \\
\text { 2019, the gender, nationality and status } \\
\text { distribution was: } 51 \% \text { women, } 49 \%, 13 \\
\% \text { non-Danish speakers and } 29 \% \\
\text { civilians during } 140 \text { events. }\end{array}$ & $\begin{array}{l}\text { Event/knowl } \\
\text { edge sharing }\end{array}$ & $\begin{array}{l}11.000 \text { participants, } \\
\text { partners, } 334 \text { speakers } \\
\text { and professionals, } 10 \\
\text { cities }\end{array}$ \\
\hline $\begin{array}{l}\text { OGP: Open } \\
\text { government } \\
\text { partnership } \\
(2011)\end{array}$ & $\begin{array}{l}\text { International partnership with nearly } 78 \\
\text { countries. The aim is to use technology } \\
\text { to improve societies by ensuring } \\
\text { transparency, democracy, and } \\
\text { accountability. Aarhus Open Data } \\
\text { project plays central role in the } \\
\text { organization. }\end{array}$ & $\begin{array}{l}\text { Partnership/ } \\
\text { knowledge } \\
\text { sharing }\end{array}$ & $\begin{array}{l}\text { Danish government, } \\
\text { the Danish } \\
\text { digitalization agency, } \\
78 \text { member countries }\end{array}$ \\
\hline $\begin{array}{l}\text { OASC - Open } \\
\text { and agile smart } \\
\text { cities } \\
(2015)\end{array}$ & $\begin{array}{l}\text { International smart city network. } \\
\text { The goal of the network is to build the } \\
\text { foundation for a global smart tech } \\
\text { market where digital services and } \\
\text { solutions can be scaled sustainably. } \\
\text { Smart Aarhus was among the founding } \\
\text { partners. }\end{array}$ & $\begin{array}{l}\text { Data/ } \\
\text { partnership/s } \\
\text { mart city } \\
\text { market/ } \\
\text { sustainable } \\
\text { development }\end{array}$ & $\begin{array}{l}\text { More than } 140 \text { cities } \\
\text { from } 30 \text { countries in } \\
\text { Europe, Latin } \\
\text { America, Asia, and } \\
\text { Australia }\end{array}$ \\
\hline $\begin{array}{l}\text { Smart city } \\
\text { network } \\
(2013)\end{array}$ & $\begin{array}{l}\text { Danish smart city network providing a } \\
\text { common platform for organizations and } \\
\text { institutions across sectors. Provides } \\
\text { knowledge and overview of smart city } \\
\text { activities and best practice cases in } \\
\text { Denmark. }\end{array}$ & $\begin{array}{l}\text { Knowledge } \\
\text { sharing/colla } \\
\text { boration }\end{array}$ & $\begin{array}{l}\text { Driven by State of } \\
\text { Green, Gate21, CITY } \\
\text { PACK, CLEAN and } \\
\text { Dansk } \\
\text { Byplanslaboratorium }\end{array}$ \\
\hline $\begin{array}{l}\text { IoT forum- } \\
\text { Internet of Things } \\
\text { International } \\
\text { Forum } \\
(2013)\end{array}$ & $\begin{array}{l}\text { member-based forum/organization } \\
\text { aimed at developing an ecosystem for } \\
\text { the Internet of Things which seek } \\
\text { solutions to technological, business, and } \\
\text { societal barriers. Aims to improve } \\
\text { circumstances for a global Internet of } \\
\text { Things market, and thereby promote } \\
\text { international cooperation amongst actors } \\
\text { across sectors. }\end{array}$ & $\begin{array}{l}\text { Knowledge } \\
\text { sharing/colla } \\
\text { boration/Mar } \\
\text { ket oriented }\end{array}$ & $\begin{array}{l}\text { Alexandria institute, } \\
\text { and international } \\
\text { actors' public } \\
\text { institutions, smart tech } \\
\text { industry, and } \\
\text { international research } \\
\text { institutions. }\end{array}$ \\
\hline
\end{tabular}




\begin{tabular}{|l|l|l|l|}
\hline $\begin{array}{l}\text { CareWare } \\
(2010)\end{array}$ & $\begin{array}{l}\text { Platform for innovation and } \\
\text { collaboration within the field of welfare } \\
\text { and health technologies. Cross -sector } \\
\text { partnership and collaboration. }\end{array}$ & $\begin{array}{l}\text { Welfare \& } \\
\text { healthcare } \\
\text { technology/ } \\
\text { partnerships }\end{array}$ & $\begin{array}{l}\text { manufacturers, } \\
\text { decision makers, } \\
\text { entrepreneurs, } \\
\text { scientists, politicians, } \\
\text { health care } \\
\text { professionals, }\end{array}$ \\
\hline
\end{tabular}

Note: Table is based on information from: www.smartaarhuseu.aarhus.dk (updated January 21, 2021)

Furthermore, as visualized in the table, the partnerships, forums, and networks Aarhus participate in, show a fragmented picture, that resemble the smart city concepts mission to be a fix - it -all concept. Moreover, by mapping various partnerships, forums, and networks that Aarhus is involved in, it is very clear, that Aarhus's smart city approach is driven by a multi- stakeholder and cross sectorial approach.

\section{Five: The smart city in practice}

The previous sections of the analysis have primarily been dedicated to analyzing how Aarhus's smart city vision is communicated and visioned in documents. This latter part of the analysis is thus devoted to exploring how the smart city vision is realized and practiced through smart city initiatives and projects in Aarhus. In this section, an analysis of smart city projects, smart city living labs, and concrete implementation of the smart city vision in Aarhus municipality's masterplan for the development of a new residential area called Lisbjerg is presented. As visualized in the following table, seventeen smart city initiatives, projects and test facilities were identified and mapped for the purpose of this analysis. The number exclude the seven smart city partnerships and networks that were previously introduced in the preceding section of this analysis.

\section{Smart City Initiatives, activities and living labs:}

\begin{tabular}{|c|c|c|c|}
\hline Name/Type & Description of project/ initiative & $\begin{array}{l}\text { Focus/dimens } \\
\text { ion }\end{array}$ & $\begin{array}{l}\text { Partners/ involved } \\
\text { actors }\end{array}$ \\
\hline \multirow[t]{2}{*}{$\begin{array}{l}\text { Aarhus City Lab } \\
\text { (2016) } \\
\text { (Previous and } \\
\text { current projects) }\end{array}$} & $\begin{array}{l}\text { IoT Crawler: making data } \\
\text { applicable via new platform. }\end{array}$ & $\begin{array}{l}\text { Data/ } \\
\text { technology/ } \\
\text { domains/ } \\
\text { strengthening } \\
\text { platforms }\end{array}$ & EU project \\
\hline & $\begin{array}{l}\text { TAPAS: testbed in Aarhus for } \\
\text { positioning autonomous systems. }\end{array}$ & $\begin{array}{l}\text { Testbed/ } \\
\text { position }\end{array}$ & $\begin{array}{l}\text { Funding: Danish } \\
\text { Agency for Data } \\
\text { Supply Efficiency }\end{array}$ \\
\hline
\end{tabular}




\begin{tabular}{|c|c|c|c|}
\hline & $\begin{array}{l}\text { Testing new technologies such as global } \\
\text { navigation satellite systems (GNSS) } \\
\text { tapasweb.dk }\end{array}$ & $\begin{array}{l}\text { determination/ } \\
\text { GNSS }\end{array}$ & $\begin{array}{l}\text { Developed with: } \\
\text { DTU Space, Aarhus } \\
\text { municipality. }\end{array}$ \\
\hline & $\begin{array}{l}\text { Open Data DK (2016): Predecessor to } \\
\text { Open Data Aarhus (ODAA) } 2013 \\
\text { An open data platform providing } \\
\text { everyone access to public data through } \\
\text { open data platform. }\end{array}$ & $\begin{array}{l}\text { Data/ } \\
\text { Data sharing }\end{array}$ & $\begin{array}{l}\text { Central Denmark } \\
\text { Region/ } \\
\text { Copenhagen/ } \\
\text { Odense/ Vejle/ } \\
\text { Aalborg }\end{array}$ \\
\hline & $\begin{array}{l}\text { Vertigo - sleep in the city (January } \\
\text { 2018-june 2019): art working to } \\
\text { addressing the importance of sleep. The } \\
\text { project promotes the message through } \\
\text { smart city technology }\end{array}$ & $\begin{array}{l}\text { Art and smart } \\
\text { technology }\end{array}$ & $\begin{array}{l}\text { EU funded } \\
\text { development project } \\
\text { START (Science, } \\
\text { Technology and } \\
\text { ARTS) }\end{array}$ \\
\hline $\begin{array}{l}\text { DOKK1 } \\
\text { Innovation } \\
\text { center }\end{array}$ & $\begin{array}{l}\text { Innovation center and physical meeting } \\
\text { space for actors involved and interested } \\
\text { in technology. } \\
\text { Home to IKT (innovation, technology, } \\
\text { creativity) and center for innovation } \\
\text { CFIA }\end{array}$ & $\begin{array}{l}\text { Testing/ } \\
\text { Operating } \\
\text { technology/ } \\
\text { physical } \\
\text { meeting space }\end{array}$ & $\begin{array}{l}\text { Smart Aarhus, IKT, } \\
\text { CFIA }\end{array}$ \\
\hline Traffic center & $\begin{array}{l}\text { Intelligent transportation systems (ITS). } \\
\text { The aim is to improve traffic flows } \\
\text { and lower CO2 emissions by using } \\
\text { artificial intelligence (AI) data and } \\
\text { machine learning. }\end{array}$ & $\begin{array}{l}\text { Efficiency/ } \\
\text { streamlining/ } \\
\text { CO2/environm } \\
\text { ent }\end{array}$ & City of Aarhus \\
\hline $\begin{array}{l}\text { Digital district } \\
\text { (2015) }\end{array}$ & $\begin{array}{l}\text { Civil dialog and digital media. } \\
\text { The project aims at encouraging citizens } \\
\text { to participate in shaping the city by } \\
\text { giving then access to phone boxes in the } \\
\text { city, where they can record their wish } \\
\text { for future development. }\end{array}$ & $\begin{array}{l}\text { Civil dialog/ } \\
\text { participation }\end{array}$ & $\begin{array}{l}\text { Citizen services } \\
\text { Aarhus municipality } \\
\text { and the Alexandria } \\
\text { institute }\end{array}$ \\
\hline $\begin{array}{l}\text { City shark } \\
(2019)\end{array}$ & $\begin{array}{l}\text { A wasteshark that keeps the harbour } \\
\text { clean by collecting waste. The drone is } \\
\text { autonomous and runs by itself }\end{array}$ & $\begin{array}{l}\text { Environment/ } \\
\text { Sustainable } \\
\text { development }\end{array}$ & $\begin{array}{l}\text { IK/ Agency for Data } \\
\text { Supply \& Efficiency, } \\
\text { Port of Aarhus/City } \\
\text { of Aarhus/external } \\
\text { suppliers }\end{array}$ \\
\hline $\begin{array}{l}\text { MaaS } \\
\text { Mobility as a } \\
\text { service }\end{array}$ & $\begin{array}{l}\text { Digital solutions supporting mobility. } \\
\text { Goal is to tackle congestion challenges } \\
\text { and shared mobility. } \\
\text { Launch of GoTur app for easy access to } \\
\text { shared mobility. }\end{array}$ & $\begin{array}{l}\text { Piolet project- } \\
\text { Smart } \\
\text { mobility/ } \\
\text { shared } \\
\text { mobility }\end{array}$ & $\begin{array}{l}\text { Teknik og miljø, } \\
\text { FDM, Gomore, } \\
\text { Rejseplanen, } \\
\text { Midttrafik }\end{array}$ \\
\hline $\begin{array}{l}\text { SmartDrones } \\
\text { Aarhus } \\
(2015)\end{array}$ & $\begin{array}{l}\text { Developing and promoting drone } \\
\text { technology in Aarhus. } \\
\text { Data collection: } \mathrm{CO} 2 \text {, pollen, heat }\end{array}$ & $\begin{array}{l}\text { Data } \\
\text { collection/ } \\
\text { drone } \\
\text { technology }\end{array}$ & $\begin{array}{l}\text { ITK (innovation, } \\
\text { technology, } \\
\text { creativity) / Aarhus } \\
\text { municipality }\end{array}$ \\
\hline
\end{tabular}




\begin{tabular}{|l|l|l|l|}
\hline $\begin{array}{l}\text { Deltagelsesportal } \\
\text { en } \\
\text { (Participation } \\
\text { portal) } \\
(2018)\end{array}$ & $\begin{array}{l}\text { A shared digital platform for citizen } \\
\text { participation and citizen hearings. The } \\
\text { platform also provides an overview of } \\
\text { participation opportunities for citizens. } \\
\text { deltag.aarhu s.dk }\end{array}$ & $\begin{array}{l}\text { Democracy } \\
\text { and } \\
\text { digitalization/ } \\
\text { citizen } \\
\text { participation }\end{array}$ & $\begin{array}{l}\text { Supported by: } \\
\text { velfærds og } \\
\text { teknologisk } \\
\text { udviklingspulje } \\
\text { (welfare technology } \\
\text { OPI -pool) }\end{array}$ \\
\hline $\begin{array}{l}\text { Center for } \\
\text { telemedicine - } \\
\text { digital Health } \\
\begin{array}{l}\text { Care } \\
\text { (2012) }\end{array}\end{array}$ & $\begin{array}{l}\text { Works with innovative digital solutions } \\
\text { for healthcare. Health care professionals } \\
\text { can support and help citizens using } \\
\text { digital solutions. }\end{array}$ & $\begin{array}{l}\text { Efficiency, } \\
\text { /health care } \\
\text { solutions }\end{array}$ & $\begin{array}{l}\text { Run by Region and } \\
\text { member for Smart } \\
\text { Aarhus }\end{array}$ \\
\hline $\begin{array}{l}\text { Narrowband } \\
\text { network in } \\
\text { Aarhus }\end{array}$ & $\begin{array}{l}\text { Narrow band network which covers } \\
\text { Aarhus Municipality. The narrowband } \\
\text { network is based on open-standard } \\
\text { LoRaWAN and Support the use of } \\
\text { sensors in the city and support other } \\
\text { municipal activities. }\end{array}$ & $\begin{array}{l}\text { Digital } \\
\text { infrastructure/ } \\
\text { efficiency/ } \\
\text { measuring/ } \\
\text { optimizing }\end{array}$ & $\begin{array}{l}\text { Smart Aarhus, } \\
\text { Aarhus municipality, }\end{array}$ \\
\hline $\begin{array}{l}\text { Lisbjerg: urban } \\
\text { Development/mas } \\
\text { terplan }\end{array}$ & $\begin{array}{l}\text { Urban development project with Smart } \\
\text { Aarhus as consulting partner }\end{array}$ & $\begin{array}{l}\text { Smart living/ } \\
\text { Sustainable } \\
\text { development }\end{array}$ & $\begin{array}{l}\text { Aarhus Municipality, } \\
\text { Smart Aarhus }\end{array}$ \\
\hline
\end{tabular}

Note: Based on information from: www.smartaarhuseu.aarhus.dk (updated January 21, 2021) and: Lisbjerg Masterplan (Aarhus Municipality - teknik \& miljø, 2018).

The mapping of smart city activities, projects and initiatives show a fragmented and comprehensive list of activities related to the smart city approach. While the list is long, a few things stand out. First, when analyzing the focus and aim of the smart city initiatives, most of the activities has been categorized under testing, experimentation, and pilot projects. This is not surprising, as informed by the theoretical framework, the smart city concept is known for its comprehensive testing activities, which does however often struggle with being scaled and permanently implemented in cities. Smart Aarhus is also addressing the topic of testing, growing, and scaling solutions, as they state in their vision:" Smart Aarhus wants to act fast, experiment, take risks, make adjustments, and grow smarter. Pilot projects are a key as long as they are sustainable and scalable." (Smart Aarhus, 2015, p. 10). Despite Smart Aarhus's aim of acting fast and scaling projects quickly, the table indicate that many projects appear to be left in the testing stage after years since launching. This may well imply, that the statement is difficult to live up to.

Furthermore, when analyzing the listed projects and activities, it is worth noticing that most of the projects and activities are defined by features explained and presented in the theory section about 
the corporate smart city and urban living labs. The listed activities may all be identified as largely driven by private and public actor partnerships, and they are mostly initiated as some type of testing and trial project and largely characterized by an aim of scaling and exporting solutions.

As shown in the table, the goals and focal points of the different projects, activities, and initiatives vary significantly, and the projects aim to solve different problems and meet various goals. Based on the mapping, is it clear that Smart Aarhus seek to deliver on all parameters meaning; Social, Economic, and Environmental aspects. Their activities range from testing technological solutions to projects that seek to target social aspects or drive economic growth, and the scope, smart city vision, and approach may therefore be understood as holistic.

As informed by the theoretical framework, social sustainability is something smart cities in general claims to support, but as informed, often fail to do. As emphasized earlier in the analysis, Smart Aarhus claim to be an alternative approach that, among others tings, works with social aspects of the smart city. Smart Aarhus is a self- declared alternative smart city model, that claim to practice a democratic citizen centered approach which, according to the city, is not found elsewhere. Smart Aarhus is highlighting their open data project open data Aarhus (ODAA) has one of the main reasons that their model is more democratic and socially sustainable compared to what is generally found. The idea is, that everyone interested in data, can access it freely on equal terms. Moreover, it is emphasized that the open data program is attractive to businesses as it provides them with valuable data, from which they may innovate and create new products and services (smart.aarhus.dk, 2021). Furthermore, as shown in table, Aarhus work with projects such as the participation portal (2018) and digital district (2015) which seek to improve citizen participation and involvement by using technology to ensure smooth and easy access for citizens to voice their opinions and desires about future development of Aarhus.

Many of smart Aarhus's activities is found to have clear environmental goals, as the main reason for implementing smart technologies. As explained in the theory section of this thesis, in contrast to experimenting with constructing entire smart cities as seen in Asian and Arab context, in European contexts, the smart city often is often practiced as smart tech solutions implemented in existing cities and the urban landscapes. In the case of Aarhus, for the most part, this is also true. However, an example of a future urban development project called Lisbjerg represent an example of how 
Aarhus's smart city approach also work as a consulting partner on a new urban development project (Aarhus Municipality - teknik \& miljø, 2018, p. 31). The Lisbjerg project is a masterplan for a new district located $9 \mathrm{~km}$ from the city center of Aarhus, and when finished, the district will be housing 25.000 new citizens. Smart Aarhus is part of the project, where their role is to support social, economic, and environmental sustainability by using the potentials of digitalization to implement effective sustainable solutions (ibid). In a slideshow published as part of a presentation of smart city activities, Aarhus Municipality elaborate further on Smart Aarhus role, and state that their vision is to deploy LPWAN, use IoT and data across domains, use technology to effectively operate the city area, manage wastewater, traffic and mobility by deploying tech solutions, and finally develop apps and information screens for the area (Teknik \& miljø- Aarhus Municipality, 2018, pp. 11-12).

\section{Discussion}

The following discussion seek to answer the research questions formulated in the beginning of this thesis, while discussing and elaborating further on the findings of the analysis.

One of the main observations made when analyzing the selected documents, is that Aarhus's approach to the smart city concept, and their way of communicating their vision, is strikingly similar to what is found elsewhere in aspiring smart cities and smart city literature. That is to some extent understandable, as the city is inspired by a strong concept, and therefore will be guided by the same actors, technologies etc. However, with that said, it does led to question to what extent social structures, demographics, and other conditions unique to the local is acknowledged and recognized for the important factors they are, or whether the appealing promises of the concept lead to important factors being overlooked- that being both economic, social, and environmental. As explained in this thesis, cities are rather preoccupied with wanting to promote and define smart city concepts for their cities. As informed by academia, critique of formulations of the smart city concept is a reemerging topic in the growing body of critical smart city literature. For cities, the concern appears to be adopting a clear and strong smart city concept which, in the eyes of academia, often lead to concepts that promises to much and paint a picture of the smart city concept as a far more promising and holistic approach, than what is often the case. The critique raised by academia is valid in the sense that the portrayal of a fixed concept is misleading when reality show, 
that the smart city materializes in various ways depending on context, and that it is in fact fragmented and diverse. However, with that said, one may question whether this is a bad thing, as the various ways of interpreting the concept, can reflect an emphasis on, and awareness of local condition, structures, and systems. Moreover, the critique of a concept that promises to much, has also been proven true in many cases. While assessing whether Aarhus live up to all their stated visions and goals is beyond the scope of this study, it is suggested that Aarhus's smart city vision should most likely to understood for what it is - namely a vision. The analysis has furthermore shown that Aarhus take a very explicit approach to dissociating itself from how the concept is interpreted in other parts of the world. However, based on the critical framework that has informed this thesis, the distancing from commercial American ways of working with the smart city, is in fact interesting, as Aarhus simultaneously are emphasizing the importance of engaging private actors in shaping the smart city transition, and much of what they are communicating, is directed at private businesses and actors.

Much of this thesis has been dedicated to exploring sustainability in the context of Aarhus smart city approach. Sustainable development is a wicked problem, and the analysis has shown, that the reemerging critique of the smart city concept as an overly optimistic concept, that promises to fix the worlds environmental and sustainability crisis through deploying technological solutions, is also to a certain degree present in Aarhus vision. As informed by the theoretical framework of this thesis, Campbell's triangular model explain how up until now, sustainable development has proven to be far from a smooth transition for the urban, as competing interests and unmergeable conditions such as societal structures, natural and environmental conditions and a capitalist system are not easily balanced and merged. The smart city concept is often presented as a holistic approach, and an answer to solving these problems through deploying smart technologies. Understanding this in the light of Campbell's theory, it seems unlikely that the smart city concept alone, should be the answer to this dilemma, as no approach so far, as managed to balance all interests and come up with one grand holistic solution.

Aarhus smart city vision is a strong, effectively communicated, and promising concept that may dazzle decision makers and steer them towards disregarding other options and solutions that do not merge with smart city ideals. Here, sustainable solutions that do not involve technological innovation and urban growth prospects may be at risk of being rejected or disregarded. Moreover, 
the many technological solutions that smart city actors predict will be invented in the future, may lead to the risk that cities and citizens rely on the hope that solutions are around the corner, while in fact, many solutions are yet to prove their worth in large scale, and in long term everyday operations. When considering this critique, relying on the smart city concept alone for sustainable development is concerning, as cities and citizens my pause and not take action, while they wait for smart solutions to be invented. In the case of Aarhus, many solutions have been stuck in the testing and trial phase for a long time, and even if the vision communicate commitment to scaling and implementing solutions fast, it may indicate that it is easier said than done.

As far as social sustainability goes, Aarhus's smart city approach does pride itself for representing an alternative approach to the concept. Aarhus's approach is emphasizing co- creation, citizen involvement, and participation, and thus claim to offer a more democratic smart city model. It may to a certain extent be true, that Aarhus offer a more democratic approach, and as shown, open data projects such as open data Aarhus (ODAA) is a leading example of how data can be collected, used and shared in a more democratic and socially sustainable way compared to what is generally found in smart cities. With that said, it is emphasized that the open data program is attractive to businesses, and that it provides them with valuable data, from which they may innovate and create new products and services. What is interesting about this, is that, on the one hand, it is said that the data project ensures more fair and democratic solutions and processes, but on the other hand, private businesses who work for profit, are encouraged to use the data to create services and products that, at the end of the day, are shaped by actors looking for profit and not necessarily what's best for the majority.

Based on these arguments, the vision should perhaps be understood as utopian when it comes to questions related to sustainability, as sustainable development is truly difficult to achieve due to conflicting goals and interests working against each other. Moreover, time and time again, the discussion of whether the private profit seeking actors are truly able to lead development in a sustainable direction, is also central to the smart city discussions. Finally, as Aarhus is claiming to be more socially aware than other aspiring smart cities, a valid question to ask, would be more socially oriented than what? What standards are they exactly comparing themselves to. 
As informed by the theoretical framework of this thesis, the smart city concept should be understood as linked to notions of the neoliberal city and the corporate smart city. In Aarhus's smart city vision and practices, this orientation has also been found to play a significant role, as both projects, activities and the overall visions emphasize factors such as economic growth, urban prosperity, export of solutions and collaboration with private actors. The great involvement of private actors in shaping the city, has already been discussed in relation to sustainability, however, this discussion also aims to address additional concerns informed by the theoretical framework of the thesis.

As addressed in the analytical part of the thesis, Aarhus smart city approach is highly engaged with private actors, and they vision a further expansion of private public partnerships through deploying the smart city concept. As informed by theory on the neoliberal smart city, one of the key matters often missing in the study of the smart city is the analysis of power structures and rearrangement of power relations driven by the implementation of smart technologies. Such analysis should not only explore shifting power relations between citizens and urban decision makers, but also address changing structures between cities and the private sector. There may exist a real threat of cities waking up in years' time, realizing that they broke down types of urban governance that worked better for most people - all in the name of technological development and a quest for more, bigger and better. If urban decision makers eliminate themselves to a point where they may still formally be running their cities, but informally, the private sector is running the show, who can truly guarantee that the city is working for the majority of people, and not just for those who adopt well to smart city ideals and technologies. Therefore, this discussion suggests an awareness of preventing the city from selling itself short, through deploying the smart city concept.

In addition to being increasingly run through collaboration between the public and private sector, the neoliberal city is furthermore highly concerned with adopting a corporate mindset and run itself like a private business. As informed by theorist David Harvey, during the neoliberal era, this has created new conditions not previously known to the urban. One of these conditions is the competitive mindsets that cities has adopted, which has spurred new modes of interurban competition and urban branding strategies. In the case of Aarhus, competition was found to play a considerable role in their smart city vision and practices as both sustainability and smart innovation was found to be viewed as competitive parameters important for the city. This discussion suggest, 
that Aarhus's size may play a part in their eager to please private actors. As bigger and stronger seem to be the never-ending message communicated in the urban era, smaller and medium size cities may be in fear of losing themselves in the race. As they often do not have as strong of a brand as capital cities, they may be more likely to compromise in the name of competition, and not stand up to private actors who seek to exploit the urban as a market.

Competition and branding as overarching goals, may also play a role in Aarhus adaptation of the smart city concept in the first place, as the concept as a brand, is both a popular trend and a strong brand to adopt. As found in the analysis, some of the so-called smart city initiatives resemble more accessories rather than necessities meaning, that some of the so - called smart city solutions, are merely technologies we already know and use, such as communication technologies and platforms. Here, an important discussion to have is whether a strong and comprehensive smart city initiative like Smart Aarhus's vision, should be understood as a branding tool, and thus to some extend is in risk of directing the focus toward technologies that are merely "nice to have" and thereby waste valuable resources and time on solutions that support smart city branding rather than tackling pressing issues. Concluding upon the previous discussions, it begs the question if the smart city concept is merely a new, and so far, successful way of practicing neoliberal ideology in the urban realm.

\section{Conclusion}

As explained in the opening parts of this thesis, the main motivation for conducting a qualitative document analysis of Aarhus third way approach to the smart city concept, was to explore the nature of their vision, and analyze it through the lens of sustainability. Furthermore, the aim of the thesis was to develop a greater understanding of how Aarhus practice their vision in real life, and to what extent the practice corresponds with their vision.

Concluding upon the analysis of this thesis, the overall analysis of Aarhus third way approach to the smart city concept shows a fragmented and comprehensive vision that, in many ways, resemble visions and strategies presented elsewhere, and studied my academia. While Aarhus claim to represent an alternative approach, the analytical analysis has found that most of their vision 
resemble and stay true to the key components of the smart city concept. Despite this finding, and as will be explained further, the difference was found not to be in the vision itself, but rather, in the realization of the vision through initiatives and activities.

As far as sustainability goes, Aarhus's smart city vision was found to express a strong ambition of using smart technologies to ensure sustainable development. Here, it was found that Aarhus is targeting both economic, social, and environmental sustainability goals through the smart city concept. With this target, Aarhus present a vision for smart sustainable development in line with what is most often found in aspiring smart cities. In the analysis, the approach was linked the notion of sustainable development and ecological modernization which is characterized by a strong belief in humankinds' ability to engineer ourselves out of current climate and sustainability crisis, while caring for the natural environment and still ensuring economic growth and prosperity.

In the investigative part of the analysis, Aarhus smart vision was linked to economic growth ideals and goals numerous times. It was found that the economic prospects of the smart city concept play a significant role for Aarhus. The engagement of the private sector in shaping Aarhus as a smart city, was found to be emphasized repeatedly throughout the documents, and Aarhus smart city vision were thus linked to the corporate smart city, which is largely defined by the corporate world, and shaped according to corporate standards and aims of creating profit from their activities. Moreover, in this section, Aarhus smart city vision was linked to characteristics central to the neoliberal city, as the private sector is embraced as a partner in shaping the city, and the city to a larger extent outsource services to private actors.

In addition to the analytical sections of the thesis, the discussion part of the study has considered the findings of the analysis, and discussed them critically, by relating them to the theoretical framework of the thesis.

In this part of the study, Aarhus strong commitment to the smart city concept was discussed, and the point was made, that the promising and well-promoted smart city concept, may to some extent be a risk for future development, as it may encourages urban decision makers to turn a blind eye to other possible solutions. If technology is collectively decided as the basis for future development, what does that do to the solutions deployed in the city, and what may be overlooked as a result of an 
overpowering focus on technological solutions. Moreover, as a strong conceptual frame is adopted, the risk of disregarding and overlooking conditions, structures and feature unique to Aarhus become higher, and the aim of achieving the smart city dream, may distort decision making. Technology as a necessity rather than accessory was also a point discussed in the section and here, the point was made that by adopting the concept, it may lead to unnecessary technologies being deployed in the name of the smart city concept.

Derived from the analysis of the sustainable features of Aarhus's smart city vision and activities, a commitment to solving social, economic, and environmental challenges, and thereby seek to support sustainability through deploying smart technologies was identified. While seemingly doable a first glance, the discussion raised some concerns based on points informed by the theoretical framework. While a motivation and good intentions of creating an equitable, prosperous, and sustainable city is unquestionably there, fundamental questions about whether sustainable development is even achievable was discussed in this thesis. Here, theories such as the planner's triangle and theory about sustainable development as a concept, was used as arguments critically questioning whether sustainable development is even possible, and if so, if the smart city concept is the solution. The discussion led to the conclusion that to a certain degree, the sustainable goals presented in Aarhus smart city vision should be perceived as utopian, as the likelihood of achieving them by deploying technologies within the current structures and economic system, seem unrealistic as sustainability is a wicked problem, that is not easily solved.

The corporate and private actors' involvement in shaping Aarhus smart city transformation is another key discussion of this thesis. As mentioned, the analysis has linked Aarhus smart city vision to both the neoliberal city and the corporate smart city. This means, that by deploying the smart city concept, private actors have an increasingly greater say in ow the city is shaped, which create a risk of lost autonomy. By handing over power to private actors, environmental and social sustainability was found to be challenged. As a corporate approach driven by profit may led to important environmental and social needs being disregard, as profit is the overall goal. While the discussion did not conclude that this is what is already happening, the importance of Aarhus not selling itself short by gradually giving up power was implied. 
The final and overall conclusion upon the research conducted in this thesis is that while Aarhus truly aim to provide an alternative approach to the smart city concept, for the most part their vision resembles those that already exist. In the case of Aarhus third way approach to the smart city concept, the analysis suggests that despite good intentions, achieving sustainable development is a wicked problem, which seems difficult to solve through a smart city transformation. Moreover, questions of power and private actor's involvement lead to arguments against social sustainability as the private sector is, as always will be, guided by profit and not necessarily what's best for the majority. These arguments as led this study to conclude, that questions about power relations, economic motivations, and fundamental challenges with merging economic, social, and environmental interests in the city may prevent Aarhus in achieving their promising vision.

\section{Final remarks and reflections}

Based on the work and research that has been done in connection to this thesis, a major thing stands out. As it ever so often is addressed by professionals working in the intersection between technology and social conditions, the need for the perspective of social science and humanities is crucial for the success of a smart city transformation. While the smart tech industry can invent and innovate, the urban is far more complex than algorithms, data collection and intelligent systems, and an interprofessional approach to the smart city is therefore key to a successful smart transformation. Moreover, the interest of social science and humanities in ongoing studies of the smart city must not be disregarded, while technology may not be of highest attention for many social science disciplines, the research is important, as the technological evolution must be analyzed critically from this standpoint.

In addition to past remark, this section also aims to provide further reflections about future research on the of Aarhus smart city approach.

The qualitative document analysis approach as applied in this study, has provided insights and elicited meaning that has led to develop a deeper understanding of Aarhus approach the smart city concept, and paved the way for a critical discussion. However, to fully assess, measure and analyze sustainable development led by the smart city concept, it would require a far more comprehensive approach and selection of methods. Based on this research, it is however suggested that a more in- 
depth analysis of social aspects and activities that is claimed to foster social sustainability can be conducted. Here, a focused small-scale study of smart city projects and activities focused on participation, democracy and smart technology would be fruitful in understanding to what extent the smart city model support social sustainability, beyond what is being communicated. 


\section{Bibliography}

Anon., n.d. sustainabledevelopment.un.org. [Online]

Available at: https://sustainabledevelopment.un.org/?menu=1300

[Accessed 23 May 2020].

Arup, 2016. Growing smart cities in Denmark- digital technology for uban imporvement and national prosperity, Denmark: Arup.

Bowen, A. G., 2009. Document Analysis as a Qualitative Research Method, s.1.: Qualitative research Journal, Vol. 9 no. 2.

businessaarhus.dk, 2020. businessaarhus.dk. [Online]

Available at: https://businessaarhus.dk/om-aarhus/styrkepositioner-i-aarhus

[Accessed 24 April 2021].

Campbell, S., 2016. In: Readings In Planning Theory. Sussex: John Wiley \& Sons, pp. 2014-240.

City of Aarhus, n.d. On the way to fossil freedom - A climate stragety for Aarhus, Aarhus: City of Aarhus - Technical Services and Environment Center for Environment and Energy.

Clark, J., 2020. Uneven Innovation - The work of smart cities. 1 ed. New York : Columbia University Press .

Coffey, A., 2013. Analysing Documents. In: The SAGE handbook of qulitative data analysis. London: London: SAGE Publications , pp. 368-379.

Copenhagen Capacity, n.d. Danish Smart Cities, sustainable living in an urban world. Copenhagen: Copenhagen Capacity - A part of Copenhagen cleantech cluster.

Damvad Analytics, 2019. Vaekst - og Jobpotentialer for Smart City i Danmark, Copenhagen: Damvad Analytics.

Dawson, A., 2017. Extreme Cities. s.1.:Verso.

Finco, A. \& Nijkamp, P., 2001. Pathways to urban sustainability. Journal of environmental policy \& planning 3:4, pp. $289-302$.

Grossi, G. \& Pianezzi, D., 2017. Smart cities: utopia or neoliberal ideology?, s.l.: Elsevier.

Hajer, M. A., 1997. The politics of environmental discourse: ecological modernization and the policy process. s.1.:Oxford University.

Harvey, D., 1989. From managerialism to entrepreneurialism: the transformation in urban governance in late capitalism. Geografiska Annaler. Series B, Human Geography, 71(1), pp. 3-17.

Harvey, D., 2007. A brief history of neoliberalism. s.1.:Oxford University.

Hollands, G. R., 2013. Critical interventions into the corporate smart city, s.1.: Cambridge Journal of Regions, Economy and Society. 
Hollands, R. G., 2008. Will the real smart city please stand up?. City, analysis of urban trends, culture, theory, policy, action, 28 November.

Joss, S. et al., 2019. The Smart City as Global Discourse: Storylines and Critical Junctures across 27 Cities, s.1.: Informa.

Lisdorf, A., 2020. Demystifying Smart Cities: Practical Perspectives on How Cities Can Leverage the Potential of New Technologies. Copenagen, Denmark: Apress.

Marvin, S. et al., 2018. Urban Living Labs - Experimenting with city futures. New York: Routledg.

Mayer, M. C. T. a. H. T., 2016. Neoliberal urbanism and uprisings across Europe . In: Urban

Uprisings: Challenging Neoliberal Urbanism in Europe. Berlin, Germany: s.n., pp. 57-92.

Mikulak, M., 2010. The Nature of Capitalism: How Green Can We Grow? , Hamilton, Canada :

MC Master University.

Ministry of foreign affairs of Denmark - invest in Denmark, 2016. investindk,com. [Online] Available at: https://investindk.com/insights/turning-denmark-into-a-leading-smart-city-nation [Accessed 28 April 2021].

Ministry of Foreing Affairs of Denmark, 2015. Focus on Smart Cities - City of Tomorrow. Focus Denmark - Business and beyond, Issue 4, pp. 60-82.

Saldaña, J., 2009. The Coding Manual for Qualitative Researchers. s.l.:SAGE Publications Ltd.

Smart Aarhus, 2015. Smart Aarhus, A scandinavian third way, Aarhus: Smart Aarhus.

smart.aarhus.dk, 2021. smart.aarhus.dk. [Online]

Available at: https://smart.aarhus.dk/om-smart-aarhus/

[Accessed 24 April 2021].

Snow, C. C., Håkonsson, D. D. \& Obel, B., 2016. A Smart City Is a collabroative community Lessons from Smart Aarhus. California Management Review Vol. 59, pp. 92-108.

State of Green, 2018 . Think Denmark, white papers for a green transition - smart cities, creating livable, sustainable and prosperous societies, s.l.: Sate of green .

Teknik \& miljø- Aarhus Municipality, 2018. Smart City i Aarhus. Aarhus: Aarhus municipality.

UN-Habitat, 2020. World Cities Report 2020, the value of sustainable urbanization, Nairobi:

United Nations Human Settlement programme (UN-Habitat).

Unitd Nations, 1992. Agenda 21, s.1.: United Nations.

United Nations, 2020. www.sustainabledevelopment.un.org. [Online]

Available at: https://sustainabledevelopment.un.org/?menu=1300

[Accessed 9 April 2020].

urbandevelopmentcph.kk.dk, n.d. urbandevelopmentcph.kk.dk/indhold/smart-city. [Online]

Available at: https://urbandevelopmentcph.kk.dk/indhold/smart-city

[Accessed 24 April 2021]. 
Vanolo, A., 2014. Smartmentality: The smart city as Disciplinary Strategy. Urbanstudies , April. Aarhus i tal, 2021. Aarhus i tal. [Online]

Available at: https://ledelsesinformation.aarhuskommune.dk/aarhus-i-tal

[Accessed 24 April 2021].

Aarhus Municipality - teknik \& miljø, 2018. Udviklingsplan - Lisbjerg, En del af Aarhus midt $i$ landskabet. Aarhus: Aarhus Municipality.

Aarhus Municipality - Teknik og Miljø, 2019. Et attraktivt og baredygtigt Aarhus for alle pejlemaerker 2019 -2021, Aarhus: Aarhus Municipality - Teknik og Miljø.

Aarhus Municipality, 2016. Sådan arbejder Aarhus kommune med smart city. Aarhus: Aarhus Kommune.

Arup, 2016. Growing smart cities in Denmark- digital technology for uban imporvement and national prosperity, Denmark: Arup.

Ministry of Foreing Affairs of Denmark, 2015. Focus on Smart Cities - City of Tomorrow. Focus Denmark - Business and beyond, Issue 4, pp. 60-82.

State of Green, 2018 . Think Denmark, white papers for a green transition - smart cities, creating livable, sustainable and prosperous societies, s.1.: Sate of green .

Smart Aarhus, 2015. Smart Aarhus, A scandinavian third way, Aarhus: Smart Aarhus.

Teknik \& miljø- Aarhus Municipality, 2018. Smart City i Aarhus. Aarhus: Aarhus municipality. 
